\title{
Nitrogen addition accelerates the nitrogen cycle in a young subtropical Cunninghamia lanceolata (Lamb.) plantation
}

\author{
Qiufang Zhang ${ }^{1,2} \cdot$ Jiacong Zhou ${ }^{1,2} \cdot$ Xiaojie $\mathrm{Li}^{1,2} \cdot$ Chengchung $\mathrm{Liu}^{3} \cdot$ Weisheng $\mathrm{Lin}^{1,2} \cdot$ Wei Zheng ${ }^{1,2} \cdot$ \\ Yuehmin Chen ${ }^{1,2}$ (1) $\cdot$ Yusheng Yang ${ }^{1,2}$
}

Received: 29 August 2018 / Accepted: 7 March 2019 / Published online: 2 April 2019

(C) INRA and Springer-Verlag France SAS, part of Springer Nature 2019

\begin{abstract}
- Key message The nitrogen ( $\mathrm{N}$ ) cycle is likely to accelerate under future climate change. Leaf $\delta^{15} \mathrm{~N}$ enrichment factor is an indicator of $\mathbf{N}$ status in young Cunninghamia lanceolata (Lamb.) plantation ecosystems. Given that $\mathbf{N}$ dynamics across the plant-soil continuum respond more strongly to $\mathrm{N}$ addition during the dry season when $\mathrm{N}$ leaching is minimal, fertilization during this period represents an optimal strategy for improving soil fertility.

- Context The effects of $\mathrm{N}$ deposition on $\mathrm{N}$ dynamics across the plant-soil continuum in subtropical regions are poorly understood.

- Aims We investigated the effects of $\mathrm{N}$ addition on the $\mathrm{N}$ dynamics across the plant-soil continuum in young C. lanceolata plantations in different seasons as well as the effects of $\mathrm{N}$ addition on the soil microbial community.

- Methods During the dry and wet seasons, we measured the concentrations of soil inorganic N, dissolved organic $\mathrm{N}$ in soil solution, leaf and root $\mathrm{N}$ concentrations, and stable isotope abundances, and soil microbial community characteristics.

- Results Short-term N addition decreased the levels of inorganic N, dissolved organic N, and leaf N concentration in the dry season; root $\mathrm{N}$ concentration was significantly higher in the high $\mathrm{N}$ and low $\mathrm{N}$ addition plots. Irrespective of treatment, the $\mathrm{NH}_{4}{ }^{+} /$ $\mathrm{NO}_{3}{ }^{-}$ratio was higher in the wet season than in the dry season. The $\delta^{15} \mathrm{~N}$ enrichment factors of the leaf and root in our experiments were closer to zero for all $\mathrm{N}$ addition treatments. Redundancy analysis revealed that the variation in the soil microbial community had low correlation with $\mathrm{pH}$.

- Conclusion Nitrogen dynamics across the plant-soil continuum respond more strongly to $\mathrm{N}$ addition in the dry season. High $\mathrm{N}$ deposition in $\mathrm{N}$-saturated subtropical forest soil may rapidly increase leaching, particularly during the wet season. Nutrients in roots are more sensitive to changes in soil nutrient availability than those in leaves. The microbial community is primarily regulated by nutrient availability in the soil rather than by $\mathrm{pH}$.
\end{abstract}

Keywords $\mathrm{N}$ addition $\cdot \mathrm{N}$-rich $\cdot \mathrm{N}$ dynamics $\cdot$ Season

Handling Editor: Andrew Merchant

Yuehmin Chen

ymchen@fjnu.edu.cn

Yusheng Yang

geoyys@ fjnu.edu.cn

1 Key Laboratory for Humid Subtropical Eco-geographical Processes of the Ministry of Education, Fujian Normal University,

Fuzhou 350007, China

2 Institute of Geography, Fujian Normal University, Fuzhou 350007, China

3 Department of Environmental Engineering, National Ilan University, Ilan 260, Taiwan

\section{Introduction}

Nitrogen $(\mathrm{N})$ is considered the most important nutrient for growth in terrestrial ecosystems globally (Liu et al. 2017a, b, c; Wang et al. 2018a, b). Since the 1990s, human activity has greatly increased the input of biologically reactive $\mathrm{N}$ on the Earth's land surface (Galloway et al. 2008). Drastic increases in atmospheric $\mathrm{N}$ levels and subsequent deposition of $\mathrm{N}$ into plant and soil often have dramatic impacts on the structure, function, and composition of the ecosystem (Chen et al. 2015a, b; Wang et al. 2018a, b).

Most studies of $\mathrm{N}$ addition have focused on high-latitude locations, where atmospheric $\mathrm{N}$ and biological $\mathrm{N}$ fixation are relatively low (Dawes et al. 2017; Zhou et al. 2017). Less 
attention has been paid to tropical and subtropical regions, where the availability of soil $\mathrm{N}$ is considered to be high (Chen et al. 2012). Anthropogenic activities have caused noticeable increases in atmospheric $\mathrm{N}$ deposition, which is as high as $30-73 \mathrm{~kg} \mathrm{~N} \mathrm{ha}^{-1}$ in precipitation annually in some subtropical forests (Liu et al. 2013; Shi et al. 2015); this is now a serious environmental concern. The effects of $\mathrm{N}$ addition on $\mathrm{N}$ mineralization globally have been demonstrated in several previous studies (Mayor et al. 2014; Kou et al. 2018). However, it is not clear how increased $\mathrm{N}$ addition in $\mathrm{N}$-rich regions affects the $\mathrm{N}$ dynamics of the plant-soil continuum (Chen et al. 2015a, b); this limits our ability to predict the response of global forests, especially with respect to forest productivity, to increased $\mathrm{N}$.

Seasonally, dry climates exist in many regions worldwide (Kou et al. 2018). Specifically, subtropical monsoon climate is characterized by significant seasonal changes in precipitation (Xiong et al. 2018). A decrease in soil water content influences the release and mobility of $\mathrm{N}$. Monsoonal rainfall may result in severe $\mathrm{N}$ loss through drainage. It may therefore be expected that $\mathrm{N}$ addition in different seasons affect $\mathrm{N}$ dynamics of the plant-soil continuum in varying ways. For instance, evidence has shown that $\mathrm{N}$ has a more pronounced effect on leaf nutrients in the dry season than in the wet season (Kou et al. 2018). Given the important role and potential differential influences of dry season, the exploration of $\mathrm{N}$ dynamics of the plant-soil continuum in both wet and dry seasons should enhance our understanding of the effects of $\mathrm{N}$ addition on the ecosystem under future climate change scenarios.

In principle, increased $\mathrm{N}$ availability contributes to plant $\mathrm{N}$ uptake and increases growth, resulting in enhanced productivity (e.g., $29 \%$ increase in above ground; LeBauer and Treseder 2008; $35.5 \%$ increase in below ground; Xia and Wan 2008); in addition, increased $\mathrm{N}$ availability alters competition for $\mathrm{N}$ resources between plants and microorganisms (Zhou et al. 2017; Sbrana et al. 2018). Kuzyakov and Xu (2013) demonstrated that competition for $\mathrm{N}$ between the soil microbial community and plant roots in N-rich soils is lower than in $\mathrm{N}$-limited soils. Excessive $\mathrm{N}$ addition contributes to soil acidification (Tian and Niu 2015), which may have a suite of negative effects such as shifts from $\mathrm{N}$ to $\mathrm{P}$ limitation (Huang et al. 2016), nitrous oxide emissions ( $\mathrm{Zhu}$ et al. 2013; Yu et al. 2017), and considerable $\mathrm{NO}_{3}{ }^{-}$leaching from soils (Lovett and Goodale 2011; Huang et al. 2016). Tian et al. (2017) showed that the plot-averaged absolute and relative growth rates of basal area and aboveground biomass were not affected by $\mathrm{N}$ addition in a Castanopsis eyrei subtropical forest. Janssens et al. (2010) demonstrated that $\mathrm{N}$ addition reduces the distribution of plant photosynthetic products to roots and reduces their activity (Mo et al. 2007, 2008; Li et al. 2015). Such changes in productivity are important as they reflect the quantity and quality of litter and soil organic matter, all of which eventually feed back to the rate and pathways of the $\mathrm{N}$ cycle (Dawes et al. 2017).

Soil microbes are sensitive to environmental conditions, including temperature, $\mathrm{N}$ deposition, moisture, and vegetation (de Vries et al. 2012; Sugihara et al. 2015; Xu et al. 2015; Yang et al. 2015; Ma et al. 2018). Nitrogen addition is considered to enhance microbial biomass by increasing $\mathrm{C}$ and $\mathrm{N}$ resources availability in most terrestrial ecosystems limited by $\mathrm{N}$ (Zhou et al. 2017). However, it has also been reported that $\mathrm{N}$ addition to potential $\mathrm{N}$ saturation sites may constrain the activity of $\beta$-glucosidase, causing a decrease in microbial biomass (De Forest et al. 2004; Geisseler et al. 2016; Zhou et al. 2017; Wang et al. 2018a, b). Therefore, the general trends in the responses of the plant-soil continuum to $\mathrm{N}$ addition remain controversial.

Additional N may be allocated to the growth and development of new tissues, resulting in no change or a reduction in $\mathrm{N}$ concentration; however, increased plant $\mathrm{N}$ uptake may not necessarily be reflected in higher leaf $\mathrm{N}$ concentration (Chapin et al. 1995). Changes in the stable isotope abundance of $\mathrm{N}\left(\delta^{15} \mathrm{~N}\right)$ may be indicative of changes in soil $\mathrm{N}$ availability and the $\mathrm{N}$ absorption pathways of plants without requiring measurement of the changes in $\mathrm{N}$ concentration (Vallano and Sparks 2013). An increase in plant $\delta^{15} \mathrm{~N}$ enrichment factor (EF) (plant $\delta^{15} \mathrm{~N}$ minus soil $\delta^{15} \mathrm{~N}$ ) is generally associated with a relatively fast $\mathrm{N}$ cycle (Chen et al. 2010), defined as increases in the net $\mathrm{N}$ inputs and losses relative to the internal $\mathrm{N}$ cycle owing to weaker microbial $\mathrm{N}$ fixation. In the case of soil $\mathrm{N}$ deficiency, plants rely more on mycorrhizal absorption of ${ }^{15} \mathrm{~N}$-depleted organic matter. With the acceleration of soil $\mathrm{N}$ cycle and the improvement of soil $\mathrm{N}$ availability, the plant absorbs higher amounts of ${ }^{15} \mathrm{~N}$-rich inorganic $\mathrm{N}$, thus increasing plant $\delta^{15} \mathrm{~N}$ (Takebayashi et al. 2010; Hobbie and Högberg 2012). Leaf and soil $\delta^{15} \mathrm{~N}$ values show strong latitudinal gradients, which are enhanced by the increased loss of the isotopically light form of $\mathrm{N}$ and more rapid microbial processing at lower latitudes (Mayor et al. 2014). A study by Vallano and Sparks (2013) suggested that, in temperate forest ecosystems, the leaf $\delta^{15} \mathrm{~N}$ of several dominant species is affected by leaf $\mathrm{N}$ uptake, soil $\mathrm{N}$, and mycorrhizae along an $\mathrm{N}$ deposition gradient. However, evidence in support of the use of plant, soil, or ecosystem $\delta^{15} \mathrm{~N}$ values as indicators of a changing $\mathrm{N}$ cycle in subtropical forests remains scarce.

Leaf stable isotope abundance of $\mathrm{C}\left(\delta^{13} \mathrm{C}\right)$ is associated with the ratio of photosynthetic rate to stomatal conductance for water vapor (Farquhar et al. 1982; Bose et al. 2018), which can reveal the environment in which biomass was produced and be used to infer the intrinsic water utilization efficiency (iWUE). Generally, with rising atmospheric $\mathrm{CO}_{2}$ concentration, plants experience a similar diffusion of $\mathrm{CO}_{2}$ into the leaf with relatively small stomatal (Huang et al. 2016). This 
phenomenon occurs regardless of nutrient limitation, as long as such limitation does not completely inhibit photosynthesis (De Kauwe et al. 2013). Increased $\mathrm{N}$ deposition has been reported to have a positive effect on iWUE by increasing the leaf $\mathrm{N}$ concentration and photosynthetic capacity in N-poor ecosystems (Guerrieri et al. 2011). However, several studies report that excessive $\mathrm{N}$ exerts adverse effects on plant growth and leaf C gain (Magill et al. 2000; Janssens et al. 2010), which suggests that iWUE has rarely been applied to experimental $\mathrm{N}$ addition studies in $\mathrm{N}$-rich ecosystems.

Cunninghamia lanceolata (Lamb.) is widely planted in the subtropical region of southern China, and covers 9.11 million ha, accounting for approximately 18 and $5 \%$ of the total area of all forest plantations in China and globally, respectively (Huang et al. 2013; Lu et al. 2014; Lin et al. 2017). C. lanceolata serves as a good experimental subject for the purposes of this study and is additionally a tree of economic importance. We investigated the effects of $\mathrm{N}$ addition on $\mathrm{N}$ dynamics across the plant-soil continuum in this N-rich ecosystem. Specifically, we measured the concentrations of soil inorganic $\mathrm{N}$, dissolved organic $\mathrm{N}(\mathrm{DON})$ in soil solution, and $\mathrm{N}$ concentrations in leaf and root, and stable isotope abundance, as well as the soil microbial community characteristics during the dry and wet seasons. We hypothesized that (i) the effect of $\mathrm{N}$ addition on $\mathrm{N}$ dynamics in the plant-soil continuum is stronger in the dry season than in the wet season owing to large $\mathrm{N}$ loss under heavy rain condition; (ii) $\mathrm{N}$ addition enriches the plant $\delta^{15} \mathrm{~N}$ value, and this signal is evident in the plant EF.

\section{Materials and methods}

\subsection{Site description and experimental design}

The study was conducted at the Fujian Normal University's Forest Ecosystem and Global Change Research Station $\left(26^{\circ} 19^{\prime} \mathrm{N}, 117^{\circ} 36^{\prime} \mathrm{E} ; 300 \mathrm{~m}\right.$ above sea level) in Chenda Town, Sanming City, in the Fujian Province of China. The study site was located in a subtropical zone with a subtropical monsoon climate and an annual mean temperature of $19.1{ }^{\circ} \mathrm{C}$ and precipitation of $1749 \mathrm{~mm}$. Nearly $80 \%$ of yearly precipitation falls in the hot-humid wet/rainy season (AprilSeptember), and $20 \%$ falls in dry season (OctoberMarch) (Deng et al. 2010). The soil is classified as red soil under the Chinese soil classification system, which is equivalent to Oxisol in the United States Department of Agriculture Soil Taxonomy (State Soil Survey Service of China 1998; Soil Survey Staff 2014). Table 1 presents the soil characteristics.

In 2013, fifteen $2 \mathrm{~m} \times 2 \mathrm{~m}$ plots were established in the same flat area that was not significantly affected by the
Table 1 Chemical properties of the soil sampled in October 2015

\begin{tabular}{llll}
\hline Index & $\mathrm{HN}$ & $\mathrm{LN}$ & $\mathrm{CT}$ \\
\hline Soil total $\mathrm{C}\left(\mathrm{g} \mathrm{kg}^{-1}\right)$ & $12.04 \pm 0.31 \mathrm{a}$ & $11.64 \pm 0.25 \mathrm{a}$ & $12.58 \pm 0.41 \mathrm{a}$ \\
Soil total N $\left(\mathrm{g} \mathrm{kg}^{-1}\right)$ & $1.35 \pm 0.04 \mathrm{a}$ & $1.30 \pm 0.02 \mathrm{a}$ & $1.38 \pm 0.09 \mathrm{a}$ \\
Soil total P $\left(\mathrm{g} \mathrm{kg}^{-1}\right)$ & $0.25 \pm 0.01 \mathrm{a}$ & $0.24 \pm 0.01 \mathrm{a}$ & $0.21 \pm 0.01 \mathrm{~b}$ \\
Soil C/N & $8.94 \pm 0.30 \mathrm{a}$ & $8.96 \pm 0.22 \mathrm{a}$ & $9.23 \pm 0.47 \mathrm{a}$ \\
Soil C/P & $48.05 \pm 1.61 \mathrm{~b}$ & $49.02 \pm 1.97 \mathrm{~b}$ & $59.82 \pm 1.91 \mathrm{a}$ \\
Soil N/P & $5.40 \pm 0.24 \mathrm{~b}$ & $5.47 \pm 0.19 \mathrm{ab}$ & $6.56 \pm 0.42 \mathrm{a}$ \\
\hline
\end{tabular}

Value is the means of five replicates \pm standard error. Different lowercase letters in the same row indicate a significant difference $(p<0.05)$

hydrological condition in neighboring forests. The plots were separated with PVC boards inserting into the soil at a depth of $70 \mathrm{~cm}$. Four seedlings were randomly transplanted into each plot. In total, 60 healthy, uniform $C$. lanceolata seedlings were selected based on plant basal diameter, height, and fresh weight in November 2013. Average $\mathrm{N}$ deposition from precipitation in the Sanming region was $36.3 \mathrm{~kg} \mathrm{~N}^{-1}$ year $^{-1}$ (Zhang et al. 2013). A completely random block design was used, with three treatments, each with five replications: (1) control (CT, $0 \mathrm{~kg} \mathrm{~N} \mathrm{ha}^{-1}$ year $^{-1}$ ); (2) low $\mathrm{N}$ addition (LN, $40 \mathrm{~kg} \mathrm{~N} \mathrm{ha}^{-1}$ year $^{-1}$ ); and (3) high $\mathrm{N}$ addition ( $\mathrm{HN}, 80 \mathrm{~kg}$ $\mathrm{N} \mathrm{ha}^{-1}$ year $\left.{ }^{-1}\right)$. We added $\mathrm{N}$ as ammonium nitrate $\left(\mathrm{NH}_{4} \mathrm{NO}_{3}\right)$, with $\mathrm{N}$ addition being initiated in March 2014. Annually, $\mathrm{NH}_{4} \mathrm{NO}_{3}$ was divided into 12 doses and applied to the C. lanceolata plantation in each month at regular intervals. The CT plots were also treated with the same volume of deionized water without $\mathrm{NH}_{4} \mathrm{NO}_{3}$ (Liu et al. 2017a, b, c; Zhang et al. 2017).

\subsection{Soil inorganic $\mathbf{N}$ and DON}

In October 2015 (dry season) and April 2016 (wet season), five soil cores (10-cm deep, 5-cm diameter) were randomly collected from each plot. All visible roots and debris were removed before homogenizing the soil fraction of each sample. Half of the samples were stored at $4{ }^{\circ} \mathrm{C}$ until analysis for physicochemical properties. The remaining samples were stored at $-20{ }^{\circ} \mathrm{C}$ prior to microbial analysis.

Soil samples were dried for $24 \mathrm{~h}$ at $105{ }^{\circ} \mathrm{C}$ to determine gravimetric moisture. Soil $\mathrm{pH}$ was determined with a $\mathrm{pH}$ glass electrode (soil:water $=1: 2.5$ ). Soil $\mathrm{NH}_{4}{ }^{+}$and $\mathrm{NO}_{3}{ }^{-}$were extracted from $5 \mathrm{~g}$ fresh soil with $2 \mathrm{M} \mathrm{KCl}$ (soil:extract=1:4) (Allen 1989) and analyzed using a flow-injection autoanalyzer (Skalar San++, Breda, Netherlands). The soil solution was collected using the negative pressure method ( $\mathrm{Xu}$ et al. 2010). Total dissolved N (TDN) and inorganic N in soil solution were analyzed using a flow-injection autoanalyzer. Dissolved organic N (DON) in the soil solution was equal to the difference between DTN and inorganic N. 


\subsection{Soil microbes}

Soil microbial biomass carbon (MBC) and N (MBN) were extracted with $0.5 \mathrm{M}$ potassium sulfate, with and without chloroform fumigation. The amounts of $\mathrm{MBC}$ were determined using a TOC-VCPH/CPN analyzer (Elementar Analysensysteme GmbH, Germany). MBN extract solutions were analyzed using a flow-injection autoanalyzer (Skalar San++, Breda, Netherlands). MBC and MBN were calculated as the difference in extractable $\mathrm{C}$ and $\mathrm{N}$, with and without chloroform fumigation, using $k_{\mathrm{C}}$ and $k_{\mathrm{N}}$ factors of 0.45 and 0.54 , respectively (Vance et al. 1987).

We used a phospholipid fatty acid (PLFA) analysis to characterize the soil microbial community, as previously described ( $\mathrm{Li}$ et al. 2018). In short, $10 \mathrm{~g}$ freeze-dried soil was shaken with a solvent consisting of a 1:2:0.8 mixture of chloroform, methanol, and phosphate buffer $(\mathrm{pH}$ 7.4) for $2 \mathrm{~h}$. Then, the supernatant was obtained following centrifugation at $3500 \times \mathrm{g}$ for $10 \mathrm{~min}$. The remaining soil was subjected to extraction again using the same method; these two supernatants were combined and then evaporated under $\mathrm{N}_{2}$ to $1 \mathrm{~mL}$. Then, neutral glycolipids, glycolipids, and polar lipids were separated from the silicon hydroxide column by elution with chloroform, acetone, and methanol, respectively. Polar lipids were methylated using $0.2 \mathrm{M}$ methanolic $\mathrm{KOH}$ to form fatty acid methyl esters. The results for PLFA analysis were determined using a gas chromatography system (Hewlett Packard 5890 GC, Agilent, USA) fitted with the MIDI Sherlock Microbial Identification System (MIDI Inc., Newark, DE). More than 70 PLFAs were identified, ranging from $\mathrm{C} 10$ to $\mathrm{C} 24$; however, only 23 PLFAs were common to all samples. Of these, the

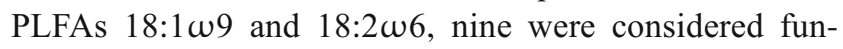
gal markers (Swallow et al. 2009). PLFAs identified as being derived from gram-positive bacteria (GP) included i14:0, i15:0, a15:0, i16:0, i17:0, and a17:0, whereas those identified as being derived from gram-negative bacteria (GN) included 16:1 $\omega 7,16: 1 \omega 9,18: 1 \omega 5$, 18:1 $\omega 7$, cy17:0, and cy19:0. The sum of PLFAs from GP and GN bacteria was used to represent total bacteria, and those of 10Me16:0, 10Me17:0, and 10Me18:0 were used to represent actinomycetes (ACT) (Frostegård et al. 2011).

\subsection{Soil $\mathbf{N}$ mineralization experiment}

We conducted a net- $\mathrm{N}$ mineralization experiment using the in situ closed-top core incubation method (Binkley and Hart 1989). On 1 October 2015, near the center of each plot, we randomly inserted two closed-top PVC tubes of length $15 \mathrm{~cm}$ and diameter $4 \mathrm{~cm}$, into the soils. On the same day, we removed one tube carefully and transferred it to the laboratory to analyze soil inorganic $\mathrm{N}\left(\mathrm{NH}_{4}{ }^{+}+\mathrm{NO}_{3}{ }^{-}\right)$. On 27 October 2015, we removed the remaining tube and transferred it to the laboratory to analyze soil available $\mathrm{N}$. The $\mathrm{N}$ mineralization rate was calculated as follows:

$\mathrm{N}$ mineralization rate

$$
=\left(\text { Mineral } \mathrm{N}_{\text {late }}-\text { Mineral } \mathrm{N}_{\text {early }}\right) / \text { day }
$$

where Mineral $\mathrm{N}_{\text {late }}$ is the inorganic $\mathrm{N}$ concentration analyzed on 27 October and Mineral $\mathrm{N}_{\text {early }}$ is the inorganic $\mathrm{N}$ concentration analyzed on 1 October.

\subsection{Plant $\mathbf{N}$ concentration and stable isotope abundance}

In both seasons, we collected current-year leaves that were fully expanded and located at the top of the branches. For fine root $(<2 \mathrm{~mm})$ sampling, five soil cores were randomly collected from each plot using a $5-\mathrm{cm}$ soil core in each plot. Large roots $(>2 \mathrm{~mm})$ were carefully removed from the soil samples using forceps and Vernier calipers; then, the soil was wet sieved through a $0.149-\mathrm{mm}$-mesh sieve. The sieved soil samples were suspended in deionized water and stirred continuously to float the fine roots to the water surface for collection (Xiong et al. 2018). The leaves and roots were oven dried at $65{ }^{\circ} \mathrm{C}$ and then weighed to the nearest $0.01 \mathrm{~g}$ using a digital balance. Dried leaves and roots were powdered using a mortar and pestle and passed through a $0.149-\mathrm{mm}$ sieve before measuring the $\mathrm{N}$ concentration and $\delta^{15} \mathrm{~N}$ value. The total $\mathrm{N}$ concentration of the leaves and roots were measured in a single analysis using a $\mathrm{CN}$ autoanalyzer (Vario Max $\mathrm{CN}$, Germany). Stable isotope abundance analyses for $\mathrm{C}$ and $\mathrm{N}$ were performed at the Stable Isotope Mass Spectrometry Laboratory at Fujian Normal University using an isotope ratio mass spectrometer (IR-MS) (MAT253, Thermo Scientific, Mdash, USA).

$\delta^{13} \mathrm{C}(\% \circ)=\left(R_{\text {sample }}-R_{\text {standard }}\right) / R_{\text {standard }} \times 1000$

where $R$ is the ratio of ${ }^{13} \mathrm{C} /{ }^{12} \mathrm{C}, R_{\text {sample }}$ is the value of sample, and $R_{\text {standard }}$ is the value of standard material. The changes in $\mathrm{C}$ isotopic discrimination $(\Delta)$ were determined based on plant $\delta^{13} \mathrm{C}$ data, using the following formula:

$\Delta=\left(\delta^{13} C_{\text {air }}-\delta^{13} C_{\text {plant }}\right) /\left(1+\delta^{13} C_{\text {plant }} / 1000\right)$

where $\delta^{13} \mathrm{C}_{\text {air }}$ and $\delta^{13} \mathrm{C}_{\text {plant }}$ are the isotopic values of the air and plant $\mathrm{CO}_{2}$, respectively. Antarctic ice core data was used to obtain data for annual $\delta^{13} \mathrm{C}_{\text {air }}$ (McCarroll 
and Loader 2004). Both intercellular $\mathrm{CO}_{2}$ concentration $\left(C_{\mathrm{i}}\right)$ and ambient $\mathrm{CO}_{2}$ concentration $\left(C_{\mathrm{a}}\right)$ are associated with $\Delta$; this relationship has been described by Farquhar et al. (1982) as follows:

$\Delta=a+(b-a)\left(C_{\mathrm{i}} / C_{\mathrm{a}}\right)$

where $a$ is the fractionation from diffusion through stomata $(=4.4 \% o)$, and $b$ is the fractionation from carboxylation by ribulose-1,5-bisphosphate carboxylase/ oxygenase $\left(=27 \%\right.$ ) . We used the $C_{\mathrm{i}} / C_{\mathrm{a}}$ data to calculate changes in plant iWUE:

$\mathrm{iWUE}=A / g=\left(C_{\mathrm{a}}-C_{\mathrm{i}}\right) / 1.6$

where 1.6 is the ratio of gaseous diffusivity of $\mathrm{CO}_{2}$ to water vapor (Ehleringer and Cerling 1995). The $C_{\mathrm{a}}$ value was obtained from Mauna Loa, Hawaii (http://www. esrl.noaa.gov/gmd/ccgg/trends/).

$\delta^{15} \mathrm{~N}(\% \circ)=\left(R_{\text {sample }}-R_{\text {standard }}\right) / R_{\text {standard }} \times 1000$

where $R$ is the ratio of ${ }^{15} \mathrm{~N} /{ }^{14} \mathrm{~N}, R_{\text {sample }}$ is the value of sample, and $R_{\text {standard }}$ is the value of standard material.

The plant (leaf or root) $\delta^{15} \mathrm{~N}$ enrichment factor (EF) was calculated as follows:

$E F=\delta^{15} N_{\text {plant }}-\delta^{15} N_{\text {soil }}$

where $\delta^{15} \mathrm{~N}_{\text {plant }}$ is the $\delta^{15} \mathrm{~N}$ of the leaf or root, and $\delta^{15} \mathrm{~N}_{\text {soil }}$ is the $\delta^{15} \mathrm{~N}$ of the soil (Garten and Miegroet 1994; Takebayashi et al. 2010).

\subsection{Statistical analysis}

All statistical analyses were performed using Origin 9.0, SPSS 20.0, and Canoco 5.0 software. For the $\mathrm{N}$ mineralization rate, which was measured only once, differences were examined using one-way analyses of variance (ANOVA). For plant and soil variables, which were measured repeatedly (plant $\mathrm{N}$ concentration, plant iWUE, plant EF, soil $\mathrm{NH}_{4}^{+}, \mathrm{NO}_{3}{ }^{-}$, DON in soil solution, $\mathrm{pH}, \mathrm{MBC}, \mathrm{MBN}$, fungi, bacteria, ACT, GP, and GN), we used linear mixed-effects models fitted with restricted maximum likelihood (REML) to assess the effects of $\mathrm{N}$ addition treatment, season, and their interaction on plant and soil variables. Fixed-effects significance was set at $p<0.05$. Plot was treated as a random factor. Treatment and all two- and three-way interactions with season were considered additional fixed effects. Significant differences between treatments during the same season for plant and soil variables (plant $\mathrm{N}$ concentration, plant iWUE, plant EF, soil $\mathrm{NH}_{4}{ }^{+}, \mathrm{NO}_{3}{ }^{-}$, DON in soil solution, $\mathrm{pH}, \mathrm{MBC}, \mathrm{MBN}$, fungi, bacteria, $\mathrm{ACT}$, GP, and GN) were tested using the multiple comparison post hoc method. For all statistical analyses, to satisfy the assumptions of normality and homogeneity of residual error, logarithmic transformation response variables were used when necessary. Redundancy analysis (RDA), which was performed using Canoco 5.0, was used to test the effects of treatment on the soil microbial community (MBC, MBN, fungi, bacteria, $\mathrm{ACT}$, GP, and GN) and environmental variables (soil $\mathrm{NH}_{4}{ }^{+}, \mathrm{NO}_{3}{ }^{-}$, inorganic $\mathrm{N}, \mathrm{DON}$ in soil solution, and $\mathrm{pH})$.

\section{Results}

\subsection{Inorganic $\mathbf{N}$ in soil extracts}

For all treatments, season had a significant effect on soil inorganic $\mathrm{N}$ concentration $(p=0.02)$, with slightly higher value in the wet season than in the dry season. Soil inorganic $\mathrm{N}$ was the highest in CT treatment and the lowest in LN treatment regardless of season (treatment $\times$ season interaction, $p=0.66$ ) (Fig. 1a, b; Table 2). During the dry season, the soil in $\mathrm{N}$ addition plots had a marginally significantly greater concentration of $\mathrm{NH}_{4}{ }^{+}$than that in $\mathrm{CT}$ plots $(+55.1$ and $57.1 \%$ in the $\mathrm{LN}$ and $\mathrm{HN}$, respectively) $(p<0.05)$ (Fig. 1a). Soil $\mathrm{NO}_{3}{ }^{-}$concentration was significantly lower, by 51.5 and $41.7 \%$, in LN and $\mathrm{HN}$ treatments, respectively, than in $\mathrm{CT}$ treatment $(p<0.05)$ (Fig. 1a). Therefore, the $\mathrm{NH}_{4}{ }^{+} / \mathrm{NO}_{3}{ }^{-}$ratio was significantly higher under the $\mathrm{LN}$ and $\mathrm{HN}$ treatments $(+215.5$ and $163.3 \%$, respectively) $(p<0.05)$ (Fig. 1c). During the wet season, soil $\mathrm{NH}_{4}{ }^{+}$concentrations did not differ among $\mathrm{N}$ addition treatments $(p>0.05)$ (Fig. 1b). Moreover, the treatment $\times$ season interactive effect on soil $\mathrm{NH}_{4}{ }^{+}$concentration was not significant $(p=0.07)$ (Table 2). The $\mathrm{NH}_{4}{ }^{+} / \mathrm{NO}_{3}{ }^{-}$ratio was significantly higher, by $97.0 \%$, under the $\mathrm{HN}$ treatment $(p<0.05)$ and lower, by $2.2 \%$, under the LN treatment $(p>0.05)$ than under the CT treatment (Fig. 1d). Consistent with the previous data, irrespective of treatment, the ratio of $\mathrm{NH}_{4}{ }^{+} / \mathrm{NO}_{3}{ }^{-}$was significantly higher in the wet season $(4.42 \pm$ 0.53 , mean \pm standard error) than in the dry season (1.12 \pm 0.13 , mean \pm standard error; $p=0.01$ ) (Fig. 1c, d; Table 2).

The $\mathrm{N}$ mineralization rate was significantly higher, by 266 and 336\%, with increased $\mathrm{N}$ addition under LN and $\mathrm{HN}$ treatments, respectively, than that under $\mathrm{CT}$ treatment $(p<0.05)$. However, there was no difference in the $\mathrm{N}$ mineralization rates between the $\mathrm{LN}$ and $\mathrm{HN}$ treatments $(p>0.05)$ (Fig. 2).

\subsection{DON in solutions}

Season had a significant effect on the DON of the soil solution $(p<0.01)$ (Table 2). DON concentration was higher in the dry season than in the wet season, irrespective of treatment. 


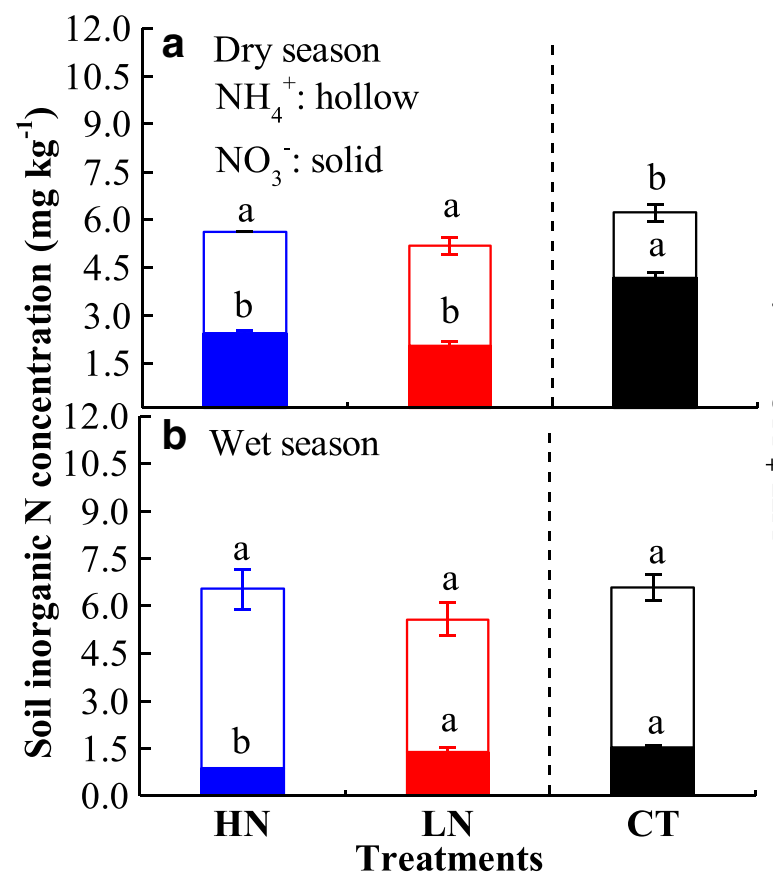

Fig. 1 KCl-extractable soil inorganic $\mathrm{N}$ (hollow bars, $\mathrm{NH}_{4}{ }^{+}$; solid bars, $\mathrm{NO}_{3}{ }^{-}$) concentration and the $\mathrm{NH}_{4}{ }^{+} / \mathrm{NO}_{3}{ }^{-}$ratio of Cunninghamia lanceolata, measured in the dry and wet seasons (a soil inorganic $\mathrm{N}$ in the dry season; $\mathbf{b}$ soil inorganic $\mathrm{N}$ in the wet season; $\mathbf{c ~} \mathrm{NH}_{4}{ }^{+} / \mathrm{NO}_{3}{ }^{-}$ratio in

During the dry season, plots with $\mathrm{LN}(p<0.05)$ and $\mathrm{HN}$ $(p>0.05)$ addition had lower DON concentration than

Table 2 Summary of results of linear mixed-effects models fitted with restricted maximum likelihood (REML) to assess the effects of $\mathrm{N}$ addition and seasonal variations for each value ( $n=5$ for averages)

\begin{tabular}{|c|c|c|c|c|c|c|}
\hline \multirow[t]{2}{*}{ Index } & \multicolumn{2}{|c|}{$\mathrm{N}$ addition } & \multicolumn{2}{|l|}{ Season } & \multicolumn{2}{|c|}{$\mathrm{N}$ addition $\times$ season } \\
\hline & $F$ & $p$ & $F$ & $p$ & $F$ & $p$ \\
\hline Leaf $\mathrm{N}$ & 2.56 & 0.12 & 113.98 & $<0.01 * *$ & 7.44 & $<0.01 * *$ \\
\hline Root N & 1.36 & 0.29 & 7.14 & $0.02 *$ & 3.78 & 0.05 \\
\hline Leaf EF & 13.81 & $<0.01 * *$ & 38.83 & $<0.01 * *$ & 0.53 & 0.60 \\
\hline Root EF & 6.74 & $0.01 *$ & 3.47 & 0.09 & 0.67 & 0.53 \\
\hline Leaf iWUE & 0.31 & 0.74 & 9.30 & $0.01 *$ & 0.46 & 0.64 \\
\hline Root iWUE & 3.02 & 0.08 & 11.25 & $<0.01 * *$ & 1.68 & 0.22 \\
\hline Soil $\mathrm{NH}_{4}^{+}$ & 2.20 & 0.15 & 56.18 & $<0.01 * *$ & 4.18 & 0.04 \\
\hline Soil $\mathrm{NO}_{3}^{-}$ & 61.57 & $<0.01 * *$ & 267.93 & $<0.01 * *$ & 35.00 & $<0.01 * *$ \\
\hline DON & 3.42 & 0.06 & 38.43 & $<0.01 * *$ & 7.37 & $<0.01 * *$ \\
\hline $\mathrm{pH}$ & 0.41 & 0.67 & 97.54 & $<0.01 * *$ & 3.19 & 0.08 \\
\hline $\mathrm{MBC}$ & 4.80 & $0.03 *$ & 17.15 & $<0.01 * *$ & 12.23 & $<0.01 * *$ \\
\hline $\mathrm{MBN}$ & 33.75 & $<0.01 * *$ & 161.13 & $<0.01 * *$ & 63.17 & $<0.01 * *$ \\
\hline Fungi & 15.58 & $<0.01 * *$ & 16.37 & $<0.01 * *$ & 18.93 & $<0.01 * *$ \\
\hline Bacteria & 17.98 & $<0.01 * *$ & 197.52 & $<0.01 * *$ & 18.14 & $<0.01 * *$ \\
\hline GP & 39.25 & $<0.01 * *$ & 196.12 & $<0.01 * *$ & 24.44 & $<0.01 * *$ \\
\hline GN & 12.59 & $<0.01 * *$ & 126.34 & $<0.01 * *$ & 13.52 & $<0.01 * *$ \\
\hline ACT & 32.46 & $<0.01 * *$ & 316.04 & $<0.01 * *$ & 22.01 & $<0.01 * *$ \\
\hline
\end{tabular}

$* p<0.05 ; * * p<0.01$

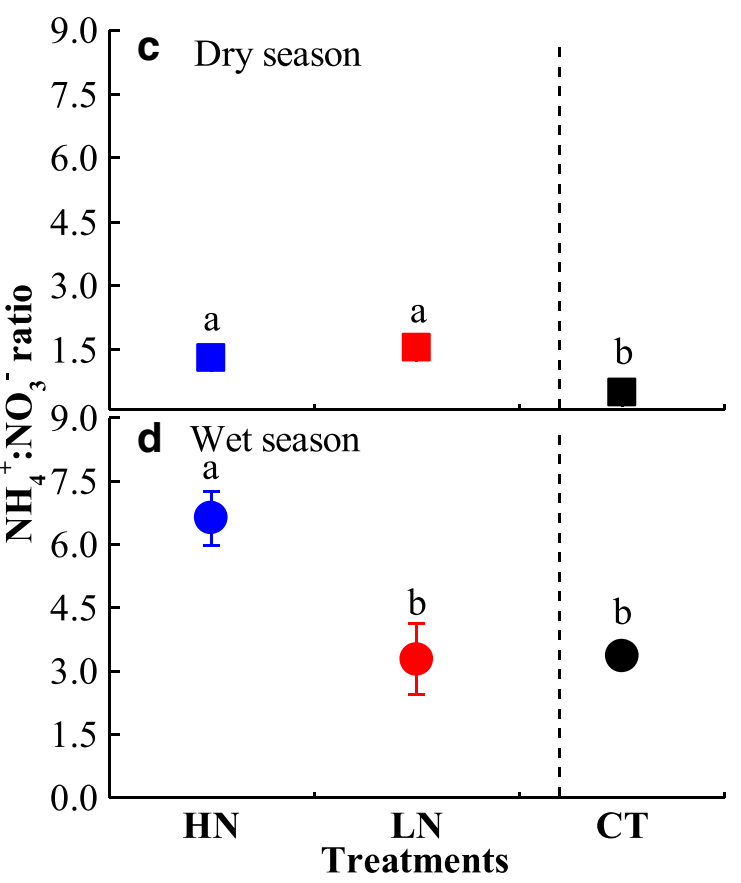

the dry season; $\mathbf{d ~ N H _ { 4 }}{ }^{+} / \mathrm{NO}_{3}{ }^{-}$ratio in the wet season). Values are the means of five replicates \pm standard error. Bars with different letters are significantly different from each other in the same season $(p<0.05)$

plots with CT. In contrast, during the wet season, LN treatment $(p<0.05)$, but no HN treatment $(p>0.05)$, significantly increased DON concentration compared with that under CT treatment. In general, DON concentration varied significantly with the treatment $\times$ season interaction $(p=0.01)$ (Fig. 3; Table 2).

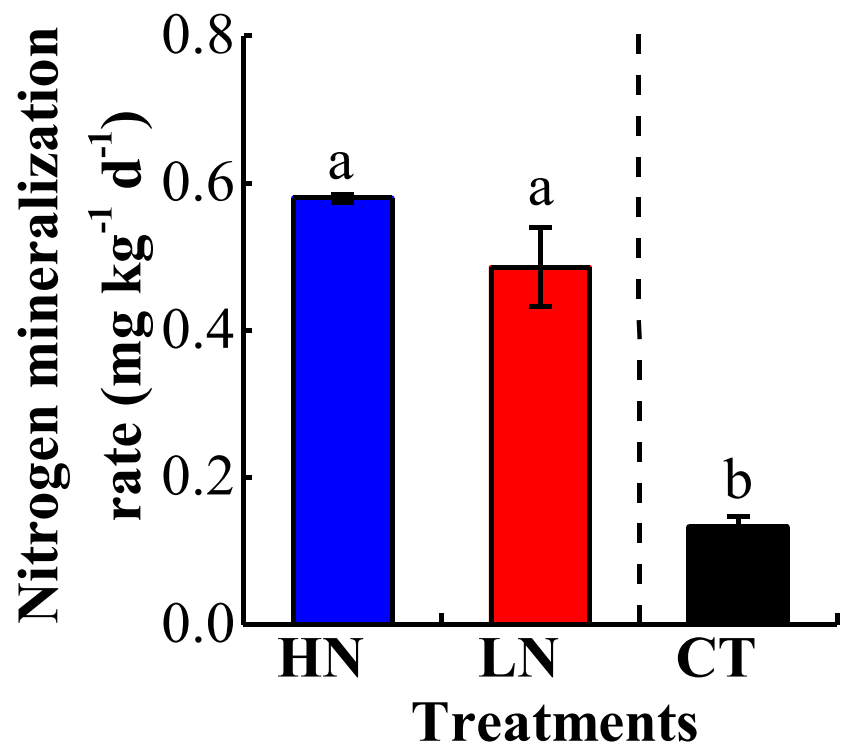

Fig. 2 Effects of $\mathrm{N}$ addition on the soil $\mathrm{N}$ mineralization rate. Values are the means of five replicates \pm standard error. Bars with different letters are significantly different from each other $(p<0.05)$ 

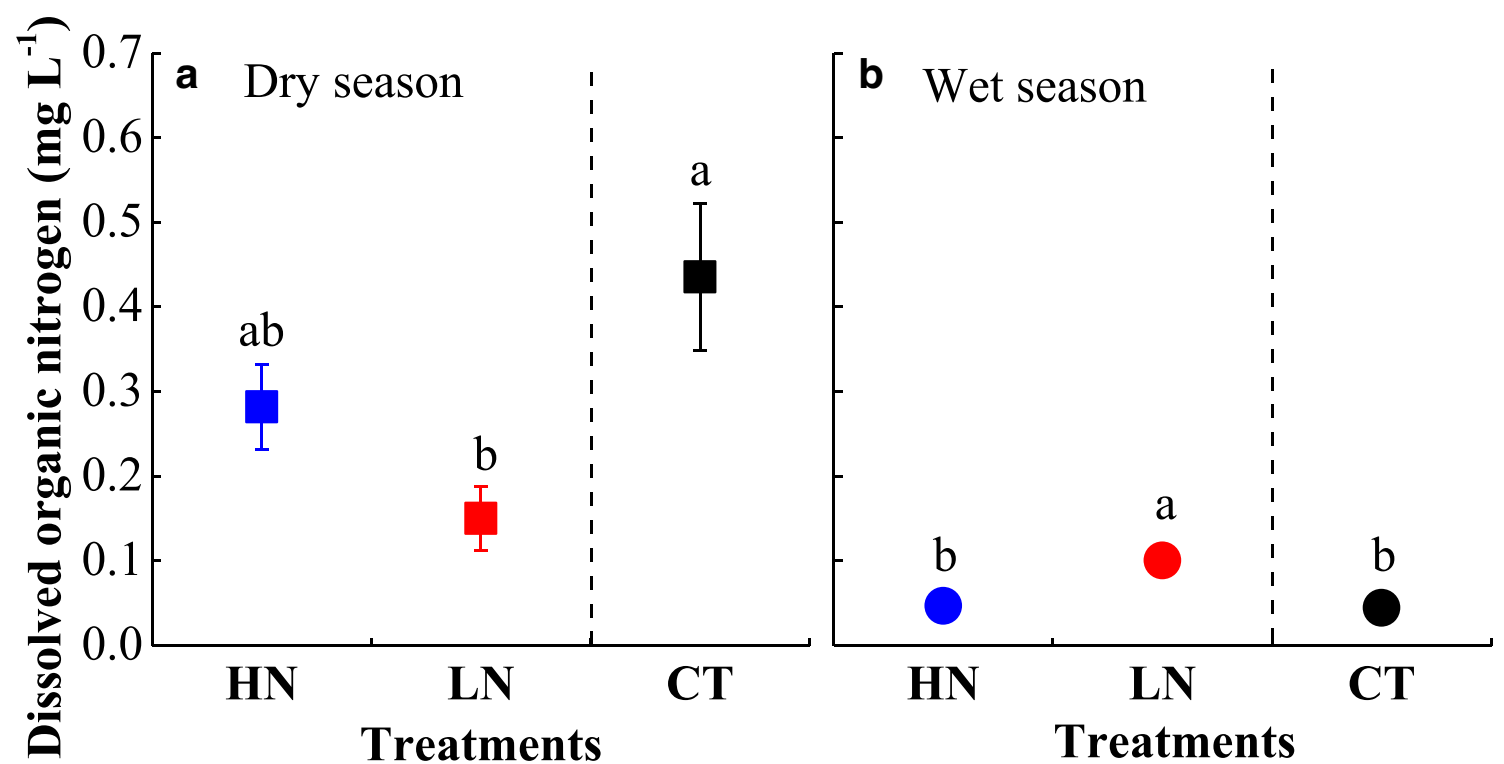

Fig. 3 Effects of $\mathrm{N}$ addition on the dissolved organic $\mathrm{N}(\mathrm{DON})$ of soil solution during the dry and wet seasons (a DON in dry season; b DON in dry season). Values are the means of five replicates \pm standard error. Bars with different letters are significantly different from each other $(p<0.05)$

\subsection{Plant $\mathbf{N}$ concentration and stable isotope abundance}

Nitrogen concentration ranged from 7.36 to $13.13 \mathrm{~g} \mathrm{~kg}^{-1}$ for leaf and from 4.36 to $6.85 \mathrm{~g} \mathrm{~kg}^{-1}$ for root (Fig. 4) and varied significantly between seasons, with a higher value observed in the dry season than in the wet season (leaf, $p<0.01$; root, $p=$ 0.02) (Table 2). A significant treatment effect was noted on leaf and root $\mathrm{N}$ concentrations of $C$. lanceolata only in the dry season (Fig. 4). Leaf $\mathrm{N}$ concentration was lower for the $\mathrm{LN}$ and $\mathrm{HN}$ treatments than for the CT treatment; this difference was present largely in LN plots $(p<0.05)$ (Fig. 4a). In contrast, root $\mathrm{N}$ concentration was significantly higher under $\mathrm{LN}$ and $\mathrm{HN}$ treatments than under CT treatment $(p<0.05)$ (Fig. $4 c)$. The interaction of treatment and season significantly affected leaf $\mathrm{N}$ concentration $(p=0.01)$, whereas the interactive effect of treatment $\times$ season on root $\mathrm{N}$ concentration was not significant $(p=0.05)$ (Table 2).

A significant effect of season was noted for EF in C. lanceolata leaf $(p<0.01)$; however, there was no

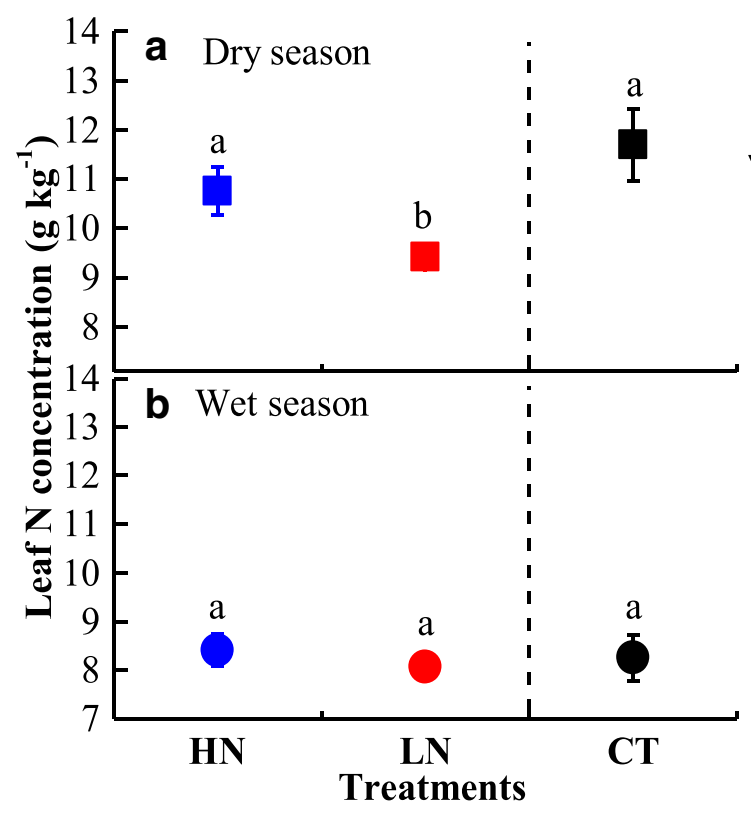

Fig. 4 Effects of $\mathrm{N}$ addition on leaf $\mathrm{N}$ and root $\mathrm{N}$ concentrations of Cunninghamia lanceolata during the dry and wet seasons (a leaf $\mathrm{N}$ concentration in the dry season; b leaf $\mathrm{N}$ concentration in the wet season; $\mathbf{c}$ root $\mathrm{N}$ concentration in the dry season; $\mathbf{d}$ root $\mathrm{N}$ concentration

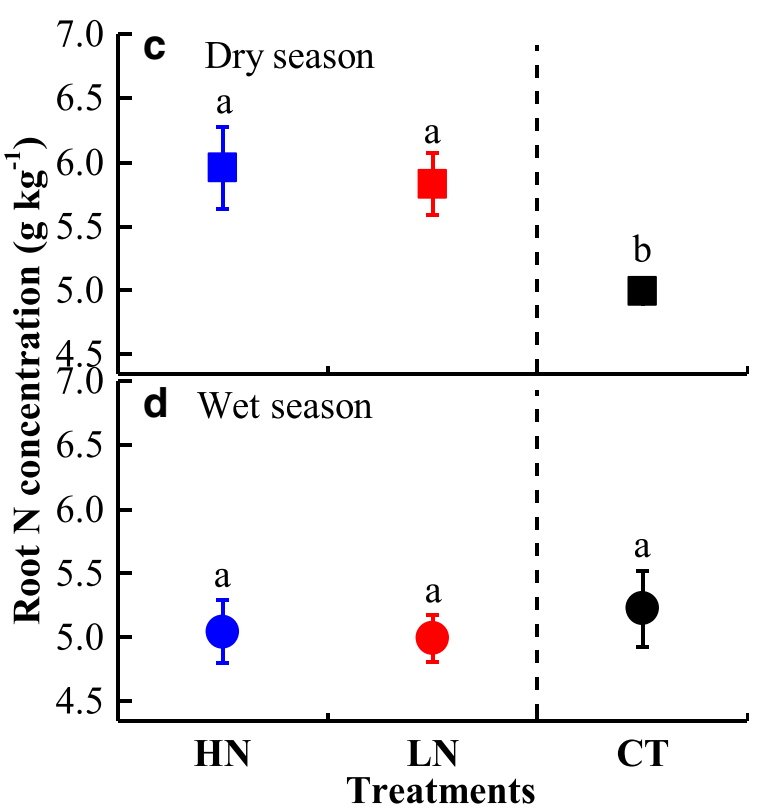

in the wet season). Values are the means of five replicates \pm standard error. Bars with different lowercase letters are significantly different from each other in the same season $(p<0.05)$ 
difference between root EF values in the dry and wet seasons $(p=0.09)$ (Table 2). C. lanceolata leaf and root $\mathrm{EF}$ values were significantly higher in $\mathrm{HN}$ plots than in CT plots $(p<0.05)$ (Fig. 5). However, interactive effects of $\mathrm{N}$ addition treatment and season were not observed for $C$. lanceolata leaf and root $\mathrm{EF}$ values (leaf, $p=0.60$; root, $p=0.53$ ) (Table 2). For leaf and root iWUE, only season had a significant effect, with higher values in the dry season than in the wet season, by 10.6 and $10.2 \%$, respectively (leaf, $p=0.10$; root, $p<0.01$ ) (Fig. 6; Table 2).

\subsection{Soil microbes}

For all treatments, microbial biomass $\mathrm{C}$ (MBC) and $\mathrm{N}$ $(\mathrm{MBN})$ were lower in the dry season than in the wet season (Table 3). In contrast, soil GP, GN, ACT, bacterial and fungal abundance showed increases in the dry season compared with their values in the wet season (GP, $p<0.01$; GN, $p<0.01$; ACT, $p<0.01$; bacterial abundance, $p<0.01$; fungal abundance, $p<0.01$ ) (Tables 2 and 3). Irrespective of season, significant treatment effects on $\mathrm{MBC}, \mathrm{MBN}, \mathrm{GP}, \mathrm{GN}, \mathrm{ACT}$, and bacterial and fungal abundance were found (MBC, $p<0.01$; $\mathrm{MBN}, p<0.01$; GP, $p<0.01$; GN, $p<0.01$; ACT, $p<0.01$; bacterial abundance, $p<0.01$; fungal abundance, $p<0.01$ ) (Table 2). In particular, during the dry season, higher values of GP, GN, ACT, and bacterial and fungal abundance were observed in $\mathrm{N}$-addition plots than in CT plots. Compared with CT treatment, interestingly, HN significantly decreased MBN (dry

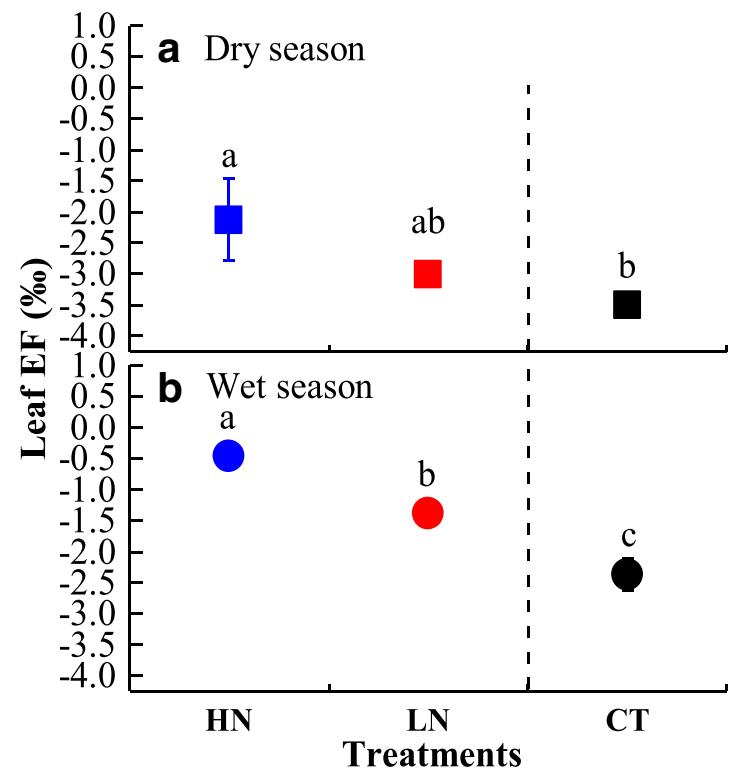

Fig. 5 Effects of $\mathrm{N}$ addition on the $\delta^{15} \mathrm{~N}$ enrichment factor (EF) of Cunninghamia lanceolata leaf and root during the dry and wet seasons (a leaf EF in the dry season; $\mathbf{b}$ leaf EF in the wet season; $\mathbf{c}$ EF in the dry season, $-23.0 \%$; wet season, $-56.0 \%)(p<0.05)$ (Table 3). There were no significant differences in $\mathrm{MBC}, \mathrm{GN}, \mathrm{ACT}$, and fungal abundance between the $\mathrm{HN}$ and LN treatments irrespective of season $(p>0.01)$. Treatment $\times$ season interactive effects were significant for all microbes (Table 2).

\subsection{Correlation between soil microbial community and physicochemical variables}

RDA indicated a significant difference in microbial community between different treatments, especially in the dry season (Fig. 7). Forward selection of the seven factors in the RDA showed that the microbial community was primarily affected by $\mathrm{NO}_{3}{ }^{-}$(dry season, $p=$ 0.002 ; wet season, $p=0.012$ ) and $\mathrm{NH}_{4}{ }^{+} / \mathrm{NO}_{3}{ }^{-}$(dry season, $p=0.004$; wet season, $p=0.008$ ) (Table 4). During the dry season, the two factors explained $63.1 \%\left(\mathrm{NO}_{3}{ }^{-}\right)$ and $53.2 \%\left(\mathrm{NH}_{4}{ }^{+} / \mathrm{NO}_{3}{ }^{-}\right)$of the variation in soil microbial community, respectively (Table 4). The concentration of $\mathrm{NO}_{3}{ }^{-}$showed a positive association significantly with $\mathrm{MBC}$, and negative associations with the ratio of fungal to bacterial abundance $(\mathrm{F} / \mathrm{B})$, and fungal abundance and ACT (Fig. 7a). However, in the wet season, the two factors explained $35.7 \%\left(\mathrm{NH}_{4}{ }^{+} / \mathrm{NO}_{3}{ }^{-}\right)$and $40.0 \%\left(\mathrm{NO}_{3}{ }^{-}\right)$of the variation in the soil microbial community, respectively (Table 4). The concentration of $\mathrm{NO}_{3}{ }^{-}$showed a positive association significantly with $\mathrm{MBN}$ and negative associations with the ratio of $\mathrm{MBC}$ to $\mathrm{MBN}(\mathrm{MBC} / \mathrm{MBN})$ (Fig. 7b) (Table 4).

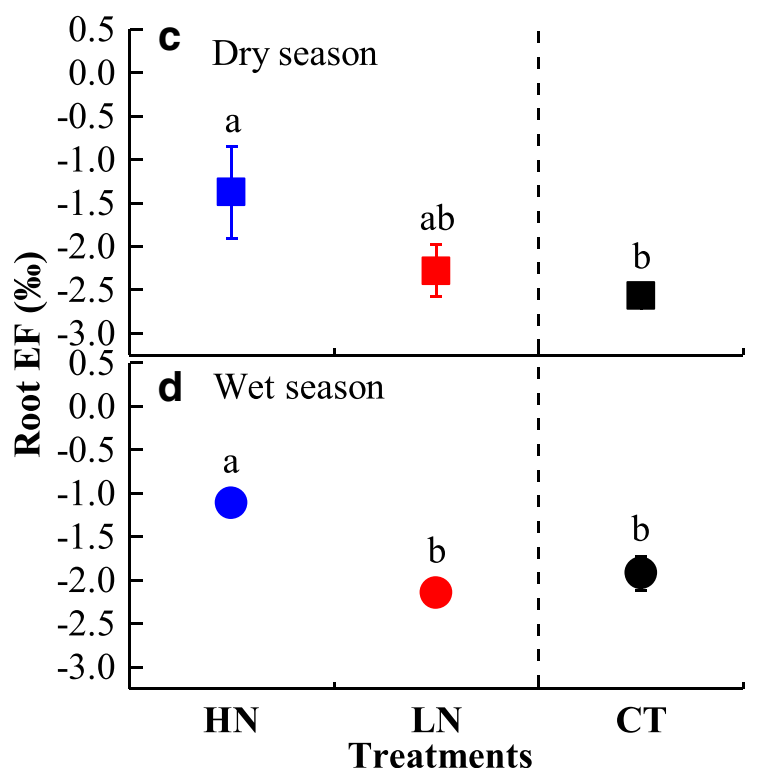

season; $\mathbf{d}$ EF in the wet season). Values are the means of five replicates \pm standard error. Bars with different lowercase letters are significantly different from each other in the same season $(p<0.05)$ 


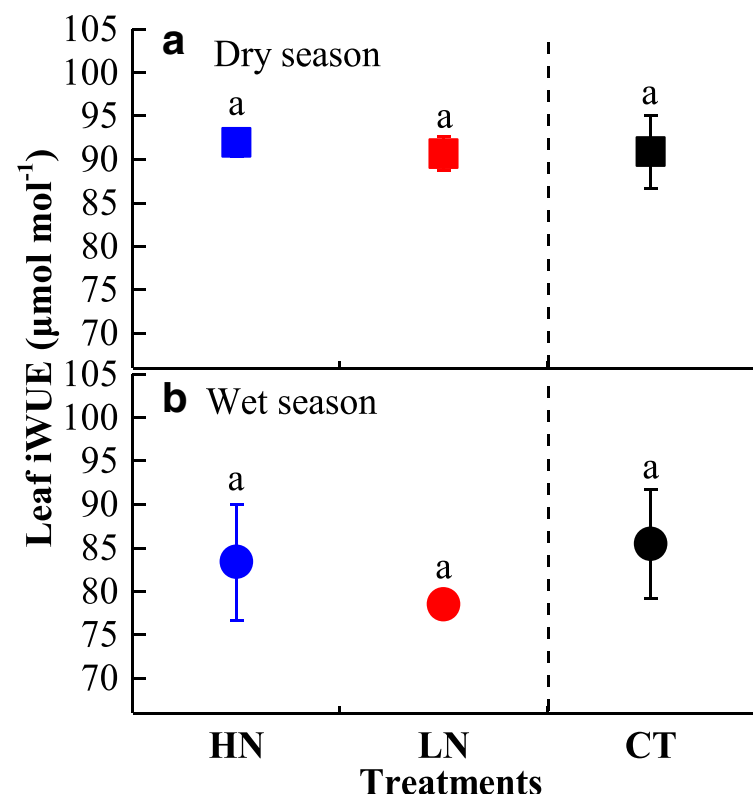

Fig. 6 Effects of $\mathrm{N}$ addition on the intrinsic water utilization efficiency (iWUE) of Cunninghamia lanceolata leaf and root during the dry and wet seasons (a leaf iWUE in the dry season; b leaf iWUE in the wet season; $\mathbf{c}$ root iWUE in the dry season; $\mathbf{d}$ root iWUE in the wet season). Values are

\section{Discussion}

\subsection{Effect of $\mathbf{N}$ addition in different seasons on $\mathbf{N}$ dynamics}

The $\mathrm{N}$ cycle is very important for forest ecosystems, and the soil $\mathrm{N}$ mineralization rate is often used as an index of soil $\mathrm{N}$

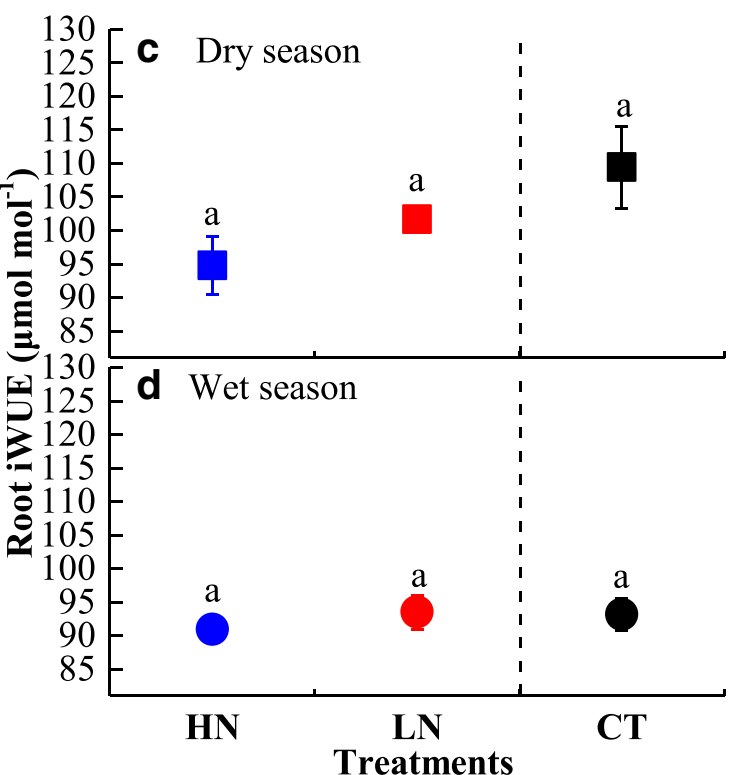

the means of five replicates \pm standard error. Bars with different lowercase letters are significantly different from each other in the same season $(p<0.05)$

availability and loss (Tian et al. 2017; Liu et al. 2017a, b, c). Consistent with the results of most previously published studies (Sardans and Peñuelas 2012), in the present study, N mineralization rate was significantly affected by $\mathrm{N}$ addition practices (Fig. 2). However, short-term $\mathrm{N}$ addition decreased inorganic N, DON, and leaf $\mathrm{N}$ concentrations in the dry season (Figs. 1, 3, and 4). Those negative effects may be attributed to

Table 3 Average value of microbial parameters and $\mathrm{pH}$ under three experimental $\mathrm{N}$ addition treatments during the dry and wet seasons

\begin{tabular}{|c|c|c|c|c|c|c|c|c|}
\hline \multirow[t]{2}{*}{ Index } & \multicolumn{4}{|l|}{ Dry season } & \multicolumn{4}{|l|}{ Wet season } \\
\hline & $\mathrm{HN}$ & $\mathrm{LN}$ & $\mathrm{CT}$ & Mean & $\mathrm{HN}$ & $\mathrm{LN}$ & CT & Mean \\
\hline $\begin{array}{l}\mathrm{MBC} \\
\quad\left(\mathrm{mg} \mathrm{kg}^{-1}\right)\end{array}$ & $151.7 \pm 3.99 b$ & $141.4 \pm 21.99 b$ & $295.2 \pm 26.83 a$ & $196.1 \pm 21.64$ & $310.6 \pm 36.19 a$ & $231.1 \pm 24.11 \mathrm{a}$ & $254.5 \pm 24.64 \mathrm{a}$ & $265.4 \pm 17.82$ \\
\hline $\begin{array}{l}\text { MBN } \\
\quad\left(\mathrm{mg} \mathrm{kg}^{-1}\right)\end{array}$ & $20.5 \pm 0.76 b$ & $16.5 \pm 1.15 b$ & $26.7 \pm 1.60 \mathrm{a}$ & $21.2 \pm 1.30$ & $19.5 \pm 2.26 \mathrm{c}$ & $56.4 \pm 3.80 \mathrm{a}$ & $44.4 \pm 1.01 b$ & $40.1 \pm 4.33$ \\
\hline GP $\left(\mathrm{nmol} \mathrm{g}^{-1}\right)$ & $15.5 \pm 0.68 \mathrm{a}$ & $10.0 \pm 0.12 b$ & $9.8 \pm 0.23 b$ & $11.8 \pm 0.74$ & $8.4 \pm 0.32 \mathrm{a}$ & $7.7 \pm 0.34 \mathrm{ab}$ & $7.0 \pm 0.38 b$ & $7.7 \pm 0.25$ \\
\hline $\begin{array}{l}\text { GN } \\
\quad\left(\mathrm{nmol} \mathrm{g}^{-1}\right)\end{array}$ & $12.6 \pm 0.50 \mathrm{a}$ & $12.5 \pm 0.13 \mathrm{a}$ & $8.4 \pm 0.54 b$ & $11.2 \pm 0.59$ & $6.6 \pm 0.54 a$ & $7.6 \pm 0.78 \mathrm{a}$ & $6.7 \pm 0.43 \mathrm{a}$ & $6.9 \pm 0.34$ \\
\hline $\begin{array}{l}\mathrm{ACT} \\
\quad\left(\mathrm{nmol} \mathrm{g}^{-1}\right)\end{array}$ & $7.5 \pm 0.48 \mathrm{a}$ & $7.4 \pm 0.20 \mathrm{a}$ & $4.3 \pm 0.13 b$ & $6.4 \pm 0.43$ & $2.8 \pm 0.13 \mathrm{a}$ & $2.7 \pm 0.19 a$ & $2.4 \pm 0.17 \mathrm{a}$ & $2.6 \pm 0.10$ \\
\hline $\begin{array}{l}\text { Bacteria } \\
\quad\left(\mathrm{nmol} \mathrm{g}^{-1}\right)\end{array}$ & $28.1 \pm 1.17 \mathrm{a}$ & $22.5 \pm 0.18 b$ & $18.2 \pm 0.62 \mathrm{c}$ & $22.9 \pm 1.16$ & $15.1 \pm 0.86 \mathrm{a}$ & $15.2 \pm 1.06 \mathrm{a}$ & $13.6 \pm 0.76 a$ & $14.6 \pm 0.52$ \\
\hline $\begin{array}{l}\text { Fungi } \\
\quad\left(\mathrm{nmol} \mathrm{g}^{-1}\right)\end{array}$ & $7.1 \pm 0.27 \mathrm{a}$ & $6.7 \pm 0.01 \mathrm{a}$ & $2.9 \pm 0.53 b$ & $5.6 \pm 0.54$ & $4.4 \pm 0.50 \mathrm{a}$ & $4.2 \pm 0.49 \mathrm{a}$ & $4.3 \pm 0.38 \mathrm{a}$ & $4.3 \pm 0.25$ \\
\hline $\mathrm{MBC} / \mathrm{MBN}$ & $7.4 \pm 0.30 \mathrm{~b}$ & $8.7 \pm 1.40 \mathrm{ab}$ & $11.1 \pm 0.88 \mathrm{a}$ & $9.1 \pm 0.66$ & $16.5 \pm 2.45 \mathrm{a}$ & $4.2 \pm 0.48 b$ & $5.8 \pm 0.66 b$ & $8.8 \pm 1.67$ \\
\hline GP/GN & $1.2 \pm 0.01 \mathrm{a}$ & $0.8 \pm 0.01 b$ & $1.2 \pm 0.03 \mathrm{a}$ & $1.07 \pm 0.06$ & $1.3 \pm 0.06 \mathrm{a}$ & $1.1 \pm 0.09 \mathrm{a}$ & $1.1 \pm 0.05 \mathrm{a}$ & $1.1 \pm 0.05$ \\
\hline $\mathrm{F} / \mathrm{B}$ & $0.3 \pm 0.01 \mathrm{a}$ & $0.3 \pm 0.01 \mathrm{a}$ & $0.2 \pm 0.03 b$ & $0.2 \pm 0.02$ & $0.3 \pm 0.02 \mathrm{a}$ & $0.3 \pm 0.01 \mathrm{a}$ & $0.3 \pm 0.04 \mathrm{a}$ & $0.3 \pm 0.02$ \\
\hline $\mathrm{pH}$ & $4.6 \pm 0.07 \mathrm{a}$ & $4.7 \pm 0.04 a$ & $4.5 \pm 0.04 \mathrm{a}$ & $4.6 \pm 0.03$ & $4.30 \pm 0.03 a$ & $4.3 \pm 0.06 \mathrm{a}$ & $4.3 \pm 0.07 \mathrm{a}$ & $4.3 \pm 0.03$ \\
\hline
\end{tabular}

Values are the means of five replicates \pm standard error. Different lowercase letters indicate significant differences from each other $(p<0.05)$ in the same season. Different capital letters are significant at $p=0.05$ between fall and spring 

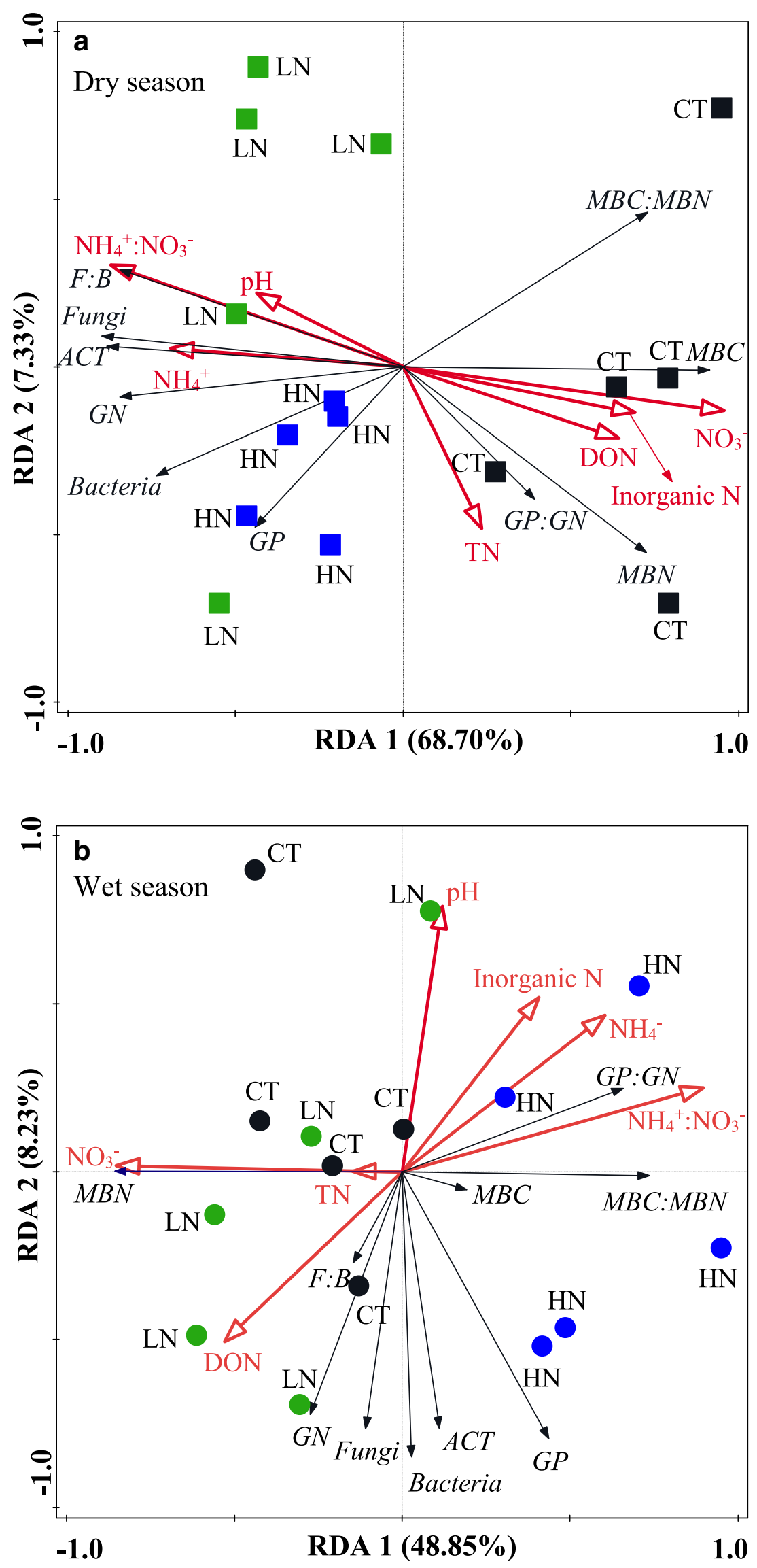
Fig. 7 Redundancy analysis ordination biplot indicating the relationships between variation in the soil microbial community (red lines) and environmental factors (black lines) (a dry season; b wet season)

(1) the decreased $\mathrm{N}$ uptake capacity of plants at sites with $\mathrm{N}$ saturation (Sardans and Peñuelas 2012), for example, Lipson et al. (1996) found that, as N reaches a certain level, Bistorta bistortoides stores $\mathrm{N}$ in amino acids and reduces $\mathrm{N}$ uptake via the roots; (2) improved uptake of $\mathrm{N}$ by microbes and roots which increases the competition for $\mathrm{N}$ between plants and microbes (Sardans and Peñuelas 2012; Liu et al. 2017a, b, c); (3) the dilution of added $\mathrm{N}$ as a result of the stimulation of growth, which potentially results in a decrease in leaf $\mathrm{N}$ concentration (Yuan and Chen 2015); and (4) the sensing of changes in soil resources by roots, which serve as the "starting point" for the entry of nutrients and water into the plant; in contrast, the response of leaves, which represent the "terminal point" for the transport of nutrients and water, may be weak or have a time lag (Schachtman and Goodger 2008; Kou et al. 2018). The last two interpretations best support the results of the present study. On the one hand, root $\mathrm{N}$ concentration was significantly higher in HN and LN plots during the dry season (Fig. 4). This result also shows that $\mathrm{N}$ in roots is more sensitive to changes in soil $\mathrm{N}$ availability than $\mathrm{N}$ in leaves, especially in the dry season. On the other hand, C. lanceolata showed a higher biomass response to both $\mathrm{HN}$ and LN treatments, as recently reported in the same study region by Xiong et al. (2018).

The soil inorganic $\mathrm{N}$ concentration for all treatments was slightly higher during the wet season than during the dry season (Fig. 1). This was related to the incorporation of a

Table 4 Correlations between environmental factors and RDA ordination of microbial parameters in different treatments during the dry and wet seasons

\begin{tabular}{|c|c|c|c|c|}
\hline Season & Environment parameters & Explains \% & $\begin{array}{l}\text { Pseudo- } \\
\text { F }\end{array}$ & $p$ value \\
\hline \multirow[t]{7}{*}{ Dry season } & $\mathrm{NO}_{3}^{-}$ & 63.1 & 22.3 & $0.002 * *$ \\
\hline & $\mathrm{NH}_{4}^{+} / \mathrm{NO}_{3}^{-}$ & 53.2 & 14.8 & $0.004 * *$ \\
\hline & $\mathrm{NH}_{4}^{+}$ & 34.3 & 6.8 & $0.010^{*}$ \\
\hline & Inorganic $\mathrm{N}$ & 33.9 & 6.7 & $0.012 *$ \\
\hline & DON & 29.1 & 5.3 & $0.016^{*}$ \\
\hline & $\mathrm{pH}$ & 13.7 & 2.1 & 0.144 \\
\hline & $\mathrm{TN}$ & 6.6 & 0.9 & 0.396 \\
\hline \multirow[t]{7}{*}{ Wet season } & $\mathrm{NO}_{3}^{-}$ & 40.0 & 8.7 & $0.008^{* *}$ \\
\hline & $\mathrm{NH}_{4}^{+} / \mathrm{NO}_{3}^{-}$ & 35.7 & 7.2 & $0.012 *$ \\
\hline & $\mathrm{NH}_{4}^{+}$ & 19.9 & 3.2 & 0.052 \\
\hline & Inorganic $\mathrm{N}$ & 16.3 & 2.5 & 0.102 \\
\hline & DON & 10.7 & 1.6 & 0.22 \\
\hline & $\mathrm{pH}$ & 6.4 & 0.9 & 0.378 \\
\hline & $\mathrm{TN}$ & 2.7 & 0.4 & 0.716 \\
\hline
\end{tabular}

$* p<0.05 ; * * p<0.01$ considerable fraction of precipitation input into the soil (Xiong et al. 2018), which likely eventually lead to a significant lowering of $\mathrm{pH}$ (Table 3 ). This finding was consistent with that reported by Cheng et al. (2014). Likewise, the shift in $C$. lanceolata leaf and root iWUE values indicated that part of the $C$. lanceolata had a lower ratio of productivity to water loss in the wet season (Fig. 6). By contrast, the concentrations of leaf and root $\mathrm{N}$ were lower in the wet season than in the dry season, irrespective of treatment. In ecosystems, there may be a number of processes that lead to a decline in plant $\mathrm{N}$ concentration in the wet season. Firstly, C. lanceolata grows faster during this period, with rapid plant cell elongation ( $\mathrm{Yu}$ 1997); therefore, additional $\mathrm{N}$ may be allocated to the growth and development of new tissues (Chapin et al. 1995). Secondly, a small DON (low-molecular-weight) is bioavailable (Dawes et al. 2017). Inagaki and Kohzu (2005) suggested that Chamaecyparis obtusa exploits the abundant $\mathrm{N}$ found in soil solution owing to severe competition for $\mathrm{NH}_{4}{ }^{+}$against soil microbes. It is possible that the lower DON at the present site in the wet season (Fig. 3) contributed directly to lower $\mathrm{N}$ uptake by $C$. lanceolata, which probably lead to the decrease in leaf and root $\mathrm{N}$ concentration. Thirdly, the reduction in root absorption activity resulted from soil water-logging in the wet season.

\subsection{Effect of $\mathrm{N}$ addition in different seasons on EF and iWUE}

The EF value generally increases with acceleration of the $\mathrm{N}$ cycle (e.g., the ratio of $\mathrm{N}$ production and demand to loss increases) (Takebayashi et al. 2010). Leaf and root EF were highest under the HN treatment and were notably different from those under the LN treatment in both dry and wet seasons (Fig. 5). Thus, the result validated our second hypothesis that higher $\mathrm{N}$ addition enriches the plant $\delta^{15} \mathrm{~N}$. The findings suggest that the $\mathrm{N}$ cycle was accelerated in response to greater $\mathrm{N}$ addition. The reason for this phenomenon is that the immobilization ability of microorganism is relatively weak under high $\mathrm{N}$ concentration, and the number of pools of $\mathrm{N}$ available to the plant is large (Hobbie and Högberg 2012; Huang et al. 2013; Dawes et al. 2017). Shifts in this direction are expected to occur with $\mathrm{N}$ addition, which likely contributes to growth in C. lanceolata (Zhang et al. 2018). An EF close to zero indicates $\mathrm{N}$ saturation, mycorrhizal infection, and relatively high available N concentration (Garten and Miegroet 1994; Hobbie and Hobbie 2006; Chen et al. 2010). Therefore, leaf EF would be suitable as an indicator of $\mathrm{N}$ status in this forest ecosystem as the $\mathrm{N}$ concentration in the leaves of $C$. lanceolata did not increase monotonically with the soil net $\mathrm{N}$ mineralization rate.

Some researchers have suggested that the changes in plant EF are attributable to the loss of isotopically light $\mathrm{N}$ through nitrification and subsequent $\mathrm{NO}_{3}{ }^{-}$leaching or denitrification (Högberg and Johannisson 1993; Schleppi et al. 2012). Via 
tracer studies with ${ }^{15} \mathrm{~N}$, Yu et al. (2017) determined that the deposited $\mathrm{NO}_{3}{ }^{-}$is directly leached without further processing, particularly under conditions of extreme $\mathrm{N}$ saturation (Lovett and Goodale 2011). Increases in $\mathrm{NH}_{4}{ }^{+} / \mathrm{NO}_{3}{ }^{-}$ratio under $\mathrm{N}$ addition, as demonstrated in the present study, were observed by Sparrius et al. (2012). They found that atmospheric N deposition is mainly derived from the breeding of domestic animals, and that high-deposition sites have elevated $\mathrm{NH}_{4}{ }^{+}$ levels, whereas equal deposition of $\mathrm{NO}_{3}{ }^{-}$is observed at high and low-deposition sites (Sparrius et al. 2012). This difference in atmospheric deposition is reflected by a higher $\mathrm{NH}_{4}{ }^{+} / \mathrm{NO}_{3}{ }^{-}$ ratio in the soil. Therefore, high $\mathrm{N}$ deposition in $\mathrm{N}$-saturated subtropical forest soil rapidly increases $\mathrm{NO}_{3}{ }^{-}$leaching, particularly during the wet season, which explains the significantly higher $\mathrm{NH}_{4}{ }^{+} / \mathrm{NO}_{3}{ }^{-}$ratio under $\mathrm{N}$ addition (Fig. 1). The present results for leaf and root $\mathrm{EF}$ under the $\mathrm{N}$ addition treatment also support the interpretation of a shift in soil $\mathrm{NH}_{4}{ }^{+} / \mathrm{NO}_{3}{ }^{-}$. For all treatments, the $\mathrm{NH}_{4}{ }^{+} \mathrm{NO}_{3}{ }^{-}$ratios were lower in the dry season, which indicated that $\mathrm{NH}_{4}{ }^{+}$may also stimulate nitrification by increasing the amount of substrate for nitrifying bacteria (Sparrius et al. 2012). Therefore, we suggest that fertilization during the dry season, when leaching is minimal, represents an optimal strategy for improving soil fertility.

In our study, iWUE showed no change under any $\mathrm{N}$ addition treatments (Fig. 6; Table 2). This is in contrast with the findings of several other studies investigating similar indicators in N-poor forests (Brooks and Coulombe 2009; Jennings 2010). Leaf $\delta^{13} \mathrm{C}$ signature and unchanged iWUE with varying nutrient availability in the present study implied that, in these $\mathrm{N}$-rich forests, $C$. lanceolata leaf $C_{\mathrm{i}} / C_{\mathrm{a}}$ remained constant as $\mathrm{N}$ addition increased. It is reasonable that C. lanceolata seedlings require large amounts of nutrients (Zhang et al. 2017) to minimize their rate of transpiration and maximize $\mathrm{C}$ assimilation (Cowan 1982; Huang et al. 2016). Although the responses of forests to $\mathrm{N}$ addition are complex, our work demonstrates that the cumulative effects of recent high $\mathrm{N}$ deposition may promote the capacity of C. lanceolata seedlings to accumulate biomass (Zhang et al. 2018).

\subsection{Relationship between the soil microbial community and physicochemical variables}

Increased $\mathrm{N}$ mineralization rate with enhanced C. lanceolata growth and acceleration of the $\mathrm{N}$ cycle may additionally stimulate microbial activity. Once base cations have been exhausted, aluminum is mobilized from soils, with soil $\mathrm{pH}$ buffered by aluminum compounds at low $\mathrm{pH}(<4.2)$ ( $\mathrm{Lu}$ et al. 2014). Tian and Niu (2015) found that $\mathrm{N}$ addition decreased microbial biomass and $\mathrm{pH}$ due to aluminum toxicity. In this case, $\mathrm{MBC}$ and $\mathrm{MBN}$ were also significantly inhibited under $\mathrm{N}$ addition in the dry season; however, the $\mathrm{pH}$ did not vary between different $\mathrm{N}$ addition treatments $(4.5 \pm 0.03$, mean \pm standard error). Wang et al. $(2018 \mathrm{a}, \mathrm{b})$ recently conducted a meta-analysis and found that decreased soil microbial biomass is associated with reduced microbial diversity under $\mathrm{N}$ addition, but not with changes in $\mathrm{pH}$. RDA consistently showed that the variation in the soil microbial community was independent of $\mathrm{pH}$ value (Fig. 7). In general, an increase in fungal abundance is associated with lower amounts of recalcitrant $\mathrm{C}$ compounds, whereas an increase in bacterial abundance is related to a decrease in labile $\mathrm{C}$ content (Cusack et al. 2011). Our results revealed that $\mathrm{N}$ addition significantly increased the ratio of $\mathrm{F} / \mathrm{B}$ in the dry season, implying a possible shift from bacterial- to fungal-dominated microbial communities. Microbial species alterations may exacerbate or mitigate the effects of changes in microbial biomass (Zhou et al. 2017). The RDA results demonstrated that the concentration of $\mathrm{NO}_{3}{ }^{-}$was predominantly negatively associated predominantly with the ratio of F/B (Fig. 7a). Therefore, the shifts in the microbial community mainly resulted from a reduction in $\mathrm{NO}_{3}{ }^{-}$rather than soil acidification. Furthermore, a potential shift in the soil microbial community is primarily regulated by nutrient availability in the soil.

\section{Conclusions}

Nitrogen mineralization rates are significantly affected by $\mathrm{N}$ addition practices. Based on analyses of the responses of $\mathrm{N}$ dynamics to $\mathrm{N}$ addition across the plant-soil continuum in N-rich regions during the dry and wet seasons, we demonstrate that the seasonal $\mathrm{N}$ addition is of significance for forest management. We suggest that fertilization during the dry season might be optimal as, during this season, $\mathrm{N}$ dynamics across the plant-soil continuum respond more strongly to $\mathrm{N}$ addition. The leaf and root $\mathrm{EF}$ in our experiments were closer to zero in all $\mathrm{N}$ addition treatments, compared with that in the control, on average. Therefore, the $\mathrm{N}$ cycle is likely to accelerate under future climate change. In particular, leaf $\mathrm{EF}$ is a potential indicator of $\mathrm{N}$ status in a $C$. lanceolata forest ecosystem. Nutrients in roots are more sensitive to changes in soil nutrient availability than those in leaves, especially in the dry season. A significant finding, which differs from those of previous studies, is that the variations in the soil microbial community are dependent on nutrient availability rather than on $\mathrm{pH}$. To summarize, our results emphasize the important roles of both seasonal changes and $\mathrm{N}$ addition in the $\mathrm{N}$ dynamics across the plant-soil continuum in N-rich regions. Our result provide a novel perspective for future research focusing on the effects of climate change on the forest ecosystem and should enable the development of optimal strategies aimed at improving forest management. 
Acknowledgments We thank anonymous reviewers and editor for their constructive and thoughtful comments on an earlier version of this manuscript. We also thank Zhijiang Liu for his help for the Soil N mineralization experiment, as well as Zhijie Yang, Decheng Xiong, Xiaofei Liu, and $\mathrm{Chao} \mathrm{Xu}$ for his help for the field sampling and platform construction.

Contribution of the co-authors Qiufang Zhang and Jiacong Zhou contributed equally to this article.

Qiufang Zhang, Jiacong Zhou, Xiaojie Li, and Wei Zheng performed the experiment.

Weisheng Lin supervised the experiment.

Chengchung Liu and Yuehmin Chen provided advices on how to write the paper.

Qiufang Zhang and Jiacong Zhou run the data analysis and wrote the paper.

Yuehmin Chen and Yusheng Yang supervised the work.

Funding The article was founded by National Natural Science Foundation of China (No. U1505233, 31,670,620, and 41,401,555).

Data availability All data are fully available without restriction. The datasets generated and/or analyzed during the current study are available in the FigShare repository (Zhang et al. 2019).

\section{Compliance with ethical standards}

Conflict of interest The authors declare that they have no conflict of interest.

\section{References}

Allen SE (1989) Chemical analysis of ecological materials. Blackwell Scientific Publications, Oxford

Binkley D, Hart SC (1989) The components of nitrogen availability assessments in forest soils. Adv Soil Sci 10:57-111

Bose AK, Nelson AS, Kane M, Rigling A (2018) Density reduction in loblolly pine (Pinus taeda $\mathrm{L}$.) stands to increase tree $\mathrm{C}$ assimilation: an approach with the dual $\delta^{13} \mathrm{C}$ and $\delta^{18} \mathrm{O}$ isotope signatures in needles. Ann For Sci 75:8

Brooks JR, Coulombe R (2009) Physiological responses to fertilization recorded in tree rings: isotopic lessons from a long-term fertilization trial. Ecol Appl 19:1044-1060

Chapin FS, Shaver GR, Giblin AE, Nadelhoffer KJ, Laundre JA (1995) Responses of Arctic tundra to experimental and observed changes in climate. Ecology 76:694-711

Chen SL, Fang HJ, Yu GR, Zhu TH, Zheng JJ (2010) Foliar and soil ${ }^{15} \mathrm{~N}$ natural abundances provide field evidence on nitrogen dynamics in temperate and boreal forest ecosystems. Plant Soil 337:285-297

Chen XM, Liu JX, Deng Q, Yan JH, Zhang DQ (2012) Effects of elevated $\mathrm{CO}_{2}$ and nitrogen addition on soil organic carbon fractions in a subtropical forest. Plant Soil 357:25-34

Chen DM, Lan ZC, Hu SJ, Bai YH (2015a) Effects of nitrogen enrichment on belowground communities in grassland: relative role of soil nitrogen availability vs. soil acidification. Soil Biol Biochem 89:99 108

Chen FS, Niklas KJ, Liu Y, Fang XM, Wan SZ, Wang HM (2015b) Nitrogen and phosphorus additions alter nutrient dynamics but not resorption efficiencies of Chinese fir leaves and twigs differing in age. Tree Physiol 35(10):1106-1117

Cheng Y, Wang J, Wang SQ, Zhang JB, Cai ZC (2014) Effects of soil moisture on gross $\mathrm{N}$ transformations and $\mathrm{N}_{2} \mathrm{O}$ emission in acid subtropical forest soils. Biol Fertil Soils 50:1099-1108
Cowan IR (1982) Regulation of water use in relation to carbon gain in higher plants. In: Lange OL, Nobel PS, Osmond CB, Ziegler H (eds) Physiological plant ecology II. Springer, Berlin, Germany, pp 589613

Cusack DF, Silver WL, Torn MS, Burton SD, Firestone MK (2011) Changes in microbial community characteristics and soil organic matter with nitrogen additions in two tropical forests. Ecology 92: $621-632$

Dawes MA, Schleppi P, Hättenschwiler S, Rixen C, Hagedorn F (2017) Soil warming opens the nitrogen cycle at the alpine treeline. Glob Chang Biol 23:421-434

De Forest JL, Zak DR, Pregitzer KS, Burton AJ (2004) Atmospheric nitrate deposition, microbial community composition, and enzyme activity in northern hardwood forests. Soil Sci Soc Am J 68:132138

De Kauwe MG, Medlyn BE, Zaehle S, Walker AP, Dietze MC, Hickler T, Jain AK, Luo Y, Parton WJ, Prentice IC (2013) Forest water use and water use efficiency at elevated $\mathrm{CO}_{2}$ : a model-data intercomparison at two contrasting temperate forest FACE sites. Glob Chang Biol 19: 1759-1779

de Vries FT, Manning P, Tallowin JR, Mortimer SR, Pilgrim ES, Harrison KA, Hobbs PJ, Quirk H, Shipley B, Cornelissen JH, Kattge J, Bardgett RD (2012) Abiotic drivers and plant traits explain landscape-scale patterns in soil microbial communities. Ecol Lett 15:1230-1239

Deng Q, Zhou GY, Liu JX, Liu SZ, Duan HL, Zhang DQ (2010) Responses of soil respiration to elevated carbon dioxide and nitrogen addition in young subtropical forest ecosystems in China. Biogeosciences 7:315-328

Ehleringer JR, Cerling TE (1995) Atmospheric $\mathrm{CO}_{2}$ and the ratio of intercellular to ambient $\mathrm{CO}_{2}$ concentrations in plants. Tree Physiol 15:105-111

Farquhar G, O'Leary M, Berry J (1982) On the relationship between carbon isotope discrimination and the intercellular carbon dioxide concentration in leaves. Funct Plant Biol 9:121-137

Frostegård Å, Tunlid A, Bååth E (2011) Use and misuse of PLFA measurements in soils. Soil Biol Biochem 43:1621-1625

Galloway JN, Townsend AR, Erisman JW, Bekunda M, Cai ZC, Freney JR, Martinelli LA, Seitzinger SP, Sutton MA (2008) Transformation of the nitrogen cycle: recent trends, questions, and potential solutions. Science 320:889-892

Garten CT, Miegroet HV (1994) Relationships between soil nitrogen dynamics and natural ${ }^{15} \mathrm{~N}$-abundance in plant foliage from the Great Smoky Mountains National Park. Can J Forest Res 24: 1636-1645

Geisseler D, Lazicki PA, Scow KM (2016) Mineral nitrogen input decreases microbial biomass in soils under grasslands but not annual crops. Appl Soil Ecol 106:1-10

Guerrieri R, Mencuccini M, Sheppard LJ, Saurer M, Perks MP, Levy P, Sutton MA, Borghetti M, Grace J (2011) The legacy of enhanced N and $\mathrm{S}$ deposition as revealed by the combined analysis of $\delta^{13} \mathrm{C}, \delta^{18} \mathrm{O}$ and $\delta^{15} \mathrm{~N}$ in tree rings. Glob Chang Biol 17:1946-1962

Hobbie JE, Hobbie EA (2006) ${ }^{15} \mathrm{~N}$ in symbiotic fungi and plants estimates nitrogen and carbon flux rates in arctic tundra. Ecology 87: $816-822$

Hobbie EA, Högberg P (2012) Nitrogen isotopes link mycorrhizal fungi and plants to nitrogen dynamics. New Phytol 196:367-382

Högberg P, Johannisson C (1993) ${ }^{15} \mathrm{~N}$ abundance of forests is correlated with losses of nitrogen. Plant Soil 157:147-150

Huang ZQ, Wan XH, He ZM, Yu ZP, Wang MH, Hu ZH, Yang YS (2013) Soil microbial biomass, community composition and soil nitrogen cycling in relation to tree species in subtropical China. Soil Biol Biochem 62:68-75

Huang ZQ, Liu B, Davis MR, Sardans J, Peñuelas J, Billings S (2016) Long-term nitrogen deposition linked to reduced water use 
efficiency in forests with low phosphorus availability. New Phytol 210:431-442

Inagaki Y, Kohzu A (2005) Microbial immobilization and plant uptake of different $\mathrm{N}$ forms in three forest types in Shikoku District, Southern Japan. Soil Sci Plant Nutr 51:667-670

Janssens IA, Dieleman W, Luyssaert S, Subke JA, Reichstein M, Ceulemans R, Ciais P, Dolman AJ, Grace J, Matteucci G, Papale D, Piao SL, Schulze ED, Tang J, Law BE (2010) Reduction of forest soil respiration in response to nitrogen deposition. Nat Geosci 3: 315-322

Jennings K (2010) Response of tree growth and water use efficiency to climate and nitrogen deposition in a temperature deciduous forest in the northeastern U.S. MA thesis, University of New Hampshire, Durham, NH, USA

Kou L, Chen WW, Jiang L, Dai XQ, Fu XL, Wang HM, Li SG (2018) Stimulated nitrogen deposition affects stoichiometry of multiple element in resource-acquiring plant organs in a seasonally dry subtropical forest. Sci Total Environ 624:611-620

Kuzyakov Y, Xu XL (2013) Competition between roots and microorganisms for nitrogen: mechanisms and ecological relevance. New Phytol 198:656-669

LeBauer DS, Treseder KK (2008) Nitrogen limitation of net primary productivity in terrestrial ecosystems is globally distributed. Ecology 89:371-379

Li WB, Jin CJ, Guan DX, Wang QK, Wang AZ, Yuan FH, Wu JB (2015) The effects of simulated nitrogen deposition on plant root traits: a meta-analysis. Soil Biol Biochem 82:112-118

Li YQ, Qing YX, Lyu MK, Chen SD, Yang ZJ, Lin CF, Yang YS (2018) Effects of artificial warming on different soil organic carbon and nitrogen pools in a subtropical plantation. Soil Biol Biochem 124: 161-167

Lin KM, Lyu MK, Jiang MH, Chen YM, Li YQ, Chen GS, Xie JS, Yang YS (2017) Improved allometric equations for estimating biomass of the three Castanopsis carlesii $\mathrm{H}$. forest types in subtropical China. New Forest 48:115-135

Lipson DA, Bowman WD, Monson RK (1996) Luxury uptake and storage on nitrogen in the rhizomatous alpine herb, Bistorta bistortoides. Ecology 77:1277-1285

Liu XJ, Zhang Y, Han WX, Tang AH, Shen JL, Cui ZL, Vitousek P, Erisman JW, Goulding K, Christie P, Fangmeier A, Zhang FS (2013) Enhanced nitrogen deposition over China. Nature 494:459 462

Liu RQ, Huang ZQ, Mccormack ML, Zhou XH, Wan XH, Yu ZP, Wang MH, Zheng LJ (2017a) Plasticity of fine-root functional traits in the litter layer in response to nitrogen addition in a subtropical forest plantation. Plant Soil 415:317-330

Liu Y, Wang CH, He NP, Wen XF, Gao Y, Li SG, Niu SL, ButterbachBahl K, Luo YQ, Yu GR (2017b) A global synthesis of the rate and temperature sensitivity of soil nitrogen mineralization: latitudinal patterns and mechanisms. Glob Chang Biol 23:455-464

Liu XF, Yang ZJ, Lin CF, Giardina CP, Xiong DC, Lin WS, Chen SD, Xu C, Chen GS, Xie JS, Li YQ, Yang YS (2017c) Will nitrogen deposition mitigate warming-increased soil respiration in a young subtropical plantation? Agric For Meteorol 246:78-85

Lovett GM, Goodale CL (2011) A new conceptual model of nitrogen saturation based on experimental nitrogen addition to an oak forest. Ecosystems 14:615-631

Lu XK, Mao QG, Gilliam FS, Luo YQ, Mo JM (2014) Nitrogen deposition contributes to soil acidification in tropical ecosystems. Glob Chang Biol 20:3790-3801

Ma S, Verheyen K, Props R, Wasof S, Vanhellemont M, Boeckx P, Boon N, De Frenne P (2018) Plant and soil microbe responses to light, warming and nitrogen addition in a temperate forest. Funct Ecol 32: $1293-1303$
Magill AH, Aber JD, Berntson GM, Mcdowell WH, Nadelhoffer KJ, Melillo JM, Steudler P (2000) Long-term nitrogen additions and nitrogen saturation in two temperate forests. Ecosystems 3:238-253

Mayor JR, Wright SJ, Schuur EAG, Brooks ME, Turner BL (2014) Stable nitrogen isotope patterns of trees and soils altered by long-term nitrogen and phosphorus addition to a lowland tropical rainforest. Biogeochemistry 119:293-306

McCarroll D, Loader NJ (2004) Stable isotopes in tree rings. Quat Sci Rev 23:771-801

Mo JM, Zhang W, Zhu WX, Fang YT, Li DJ, Zhao P (2007) Response of soil respiration to simulated $\mathrm{N}$ deposition in a disturbed and a rehabilitated tropical forest in southern China. Plant Soil 296:125-135

Mo JM, Zhang W, Zhu WX, Gundersen P, Fang YT, Li DJ, Wang H (2008) Nitrogen addition reduces soil respiration in a mature tropical forest in southern China. Glob Chang Biol 14:403-412

Sardans J, Peñuelas J (2012) The role of plants in the effects of global change on nutrient availability and stoichiometry in the plant-soil system. Plant Physiol 160:1741-1761

Sbrana C, Strani P, Pepe A, de Novais CB, Giovannetti M (2018) Divergence of Funneliformis mosseae populations over 20 years of laboratory cultivation, as revealed by vegetative incompatibility and molecular analysis. Mycorrhiza 28:329-341

Schachtman DP, Goodger JQ (2008) Chemical root to shoot signaling under drought. Trends Plant Sci 13:281-287

Schleppi P, Bucher-Wallin I, Hagedorn F, Körner C (2012) Increased nitrate availability in the soil of a mixed mature temperate forest subjected to elevated $\mathrm{CO}_{2}$ concentration (canopy FACE). Glob Chang Biol 18:757-768

Shi YL, Cui SH, Ju XT, Cai ZC, Zhu YG (2015) Impacts of reactive nitrogen on climate change in China. Sci Rep 5:8118

Soil Survey Staff (2014) Natural resources conservation service 2014 national soil survey handbook. Title 430-VI. US Government Printing Office, Washington, DC Sec 602

Sparrius LB, Sevink J, Kooijman AM (2012) Effects of nitrogen deposition on soil and vegetation in primary succession stages in inland drift sands. Plant Soil 353:261-272

State Soil Survey Service of China (1998) China soil. China Agricultural Press, Beijing

Sugihara S, Shibata M, Mvondo Ze AD, Araki S, Funakawa S (2015) Effects of vegetation on soil microbial $\mathrm{C}, \mathrm{N}$, and $\mathrm{P}$ dynamics in a tropical forest and savanna of Central Africa. Appl Soil Ecol 87:9198

Swallow M, Quideau S, MacKenzie M, Kishchuk B (2009) Microbial community structure and function: the effect of silvicultural burning and topographic variability in northern Alberta. Soil Biol Biochem 41:770-777

Takebayashi Y, Koba K, Sasaki Y, Fang YT, Yoh M (2010) The natural abundance of ${ }^{15} \mathrm{~N}$ in plant and soil-available $\mathrm{N}$ indicates a shift of main plant $\mathrm{N}$ resources to $\mathrm{NO}_{3}{ }^{-}$from $\mathrm{NH}_{4}{ }^{+}$along the $\mathrm{N}$ leaching gradient. Rapid Commun Mass Spectrom 24:1001-1008

Tian DS, Niu SL (2015) A global analysis of soil acidification caused by nitrogen addition. Environ Res Lett 10:24019-24028

Tian D, Li P, Fang WJ, Xu J, Luo YK, Yan ZB, Zhu B, Wang JJ, Xu XN, Fang JY (2017) Growth responses of trees and understory plants to nitrogen fertilization in a subtropical forest in China. Biogeosciences 14:3461-3469

Vallano DM, Sparks JP (2013) Foliar $\delta^{15} \mathrm{~N}$ is affected by foliar nitrogen uptake, soil nitrogen, and mycorrhizae along a nitrogen deposition gradient. Oecologia 172:47-58

Vance ED, Brookes PC, Jenkinson DS (1987) An extraction method for measuring soil microbial biomass C. Soil Biol Biochem 19:703-707

Wang C, Liu D, Bai E (2018a) Decreasing soil microbial diversity is associated with decreasing microbial biomass under nitrogen addition. Soil Biol Biochem 120:126-133

Wang M, Zhang WW, Li N, Liu YY, Zheng XB, Hao GY (2018b) Photosynthesis and growth responses of Fraxinus mandshurica 
Rupr. seedlings to a gradient of stimulated nitrogen deposition. Ann For Sci 75:1

Xia JY, Wan SQ (2008) Global response patterns of terrestrial plant species to nitrogen addition. New Phytol 179:428-439

Xiong DC, Yang ZJ, Chen GS, Liu XF, Lin WS, Huang JX, Bowles FP, Lin CF, Xie JS, Li YQ, Yang YS (2018) Interactive effects of warming and nitrogen addition on fine root dynamics of a young subtropical plantation. Soil Biol Biochem 122:180-189

Xu XK, Luo XB, Han L, Cao FQ, Han SJ, Gilkes RJ (2010) Effects of nitrogen addition on fluxes and concentrations of dissolved organic matter and inorganic nitrogen under a temperate old-growth forest in Northeast China. Proceedings of the 19th world congress of soil science: soil solutions for a changing world, Brisbane, Australia, 1-6 August 2010. Working group 3.2 Forest soil processes and change, 131-134

Xu ZW, Yu GR, Zhang XY, Ge JP, He NP, Wang QF, Wang D (2015) The variations in soil microbial communities, enzyme activities and their relationships with soil organic matter decomposition along the northern slope of Changbai Mountain. Appl Soil Ecol 86:19-29

Yang K, Zhu JJ, Gu JC, Yu LZ, Wang ZQ (2015) Changes in soil phosphorus fractions after 9 years of continuous nitrogen addition in a Larix gmelinii plantation. Ann For Sci 72:435-442

Yu XT (1997) Cunninghamia lanceolata cultivation science. Fujian Science and Technology Press, Sanming, pp 50-164

Yu LF, Kang RH, Mulder J, Zhu J, Dörsch P (2017) Distinct fates of atmogenic $\mathrm{NH}_{4}{ }^{+}$and $\mathrm{NO}_{3}{ }^{-}$in subtropical, $\mathrm{N}$-saturated forest soils. Biogeochemistry 133:279-294

Yuan ZY, Chen HYH (2015) Decoupling of nitrogen and phosphorus in terrestrial plants associated with global changes. Nat Clim Chang 5: 465-469
Zhang JB, Cai ZC, Zhu TB, Yang WY, Müller C (2013) Mechanisms for the retention of inorganic $\mathrm{N}$ in acidic forest soils of southern China. Sci Rep 3:2342

Zhang QF, Xie JS, Lyu MK, Xiong DC, Wang J, Chen YM, Li YQ, Wang MK, Yang YS (2017) Short-term effects of soil warming and nitrogen addition on the N:P stoichiometry of Cunninghamia lanceolata in subtropical regions. Plant Soil 411:395-407

Zhang QF, Xiong DC, Xie JS, Li XJ, You ZT, Lyu MK, Chen YM, Yang YS (2018) Ecophysiological process regulates the growth of Cunninghamia lanceolata to suit short-term warming and nitrogen addition in the sub-tropical regions. Trees 32:631-643

Zhang Q, Zhou J, Li X, Liu C, Lin W, Zheng W, Chen Y, Yang Y (2019) Nitrogen addition relatively accelerate nitrogen cycle in a young subtropical Cunninghamia lanceolata (Lamb.) plantation. V 24 January 2019. FigShare [Dataset]. https://doi.org/10.6084/m9. figshare. 7618568

Zhou ZH, Wang CK, Zheng MH, Jiang LF, Luo YQ (2017) Patterns and mechanisms of responses by soil microbial communities to nitrogen addition. Soil Biol Biochem 115:433-441

Zhu J, Mulder J, Wu LP, Meng XX, Wang YH, Drsch P (2013) Spatial and temporal variability of $\mathrm{N}_{2} \mathrm{O}$ emissions in a subtropical forest catchment in China. Biogeosciences 10:1309-1321

Publisher's note Springer Nature remains neutral with regard to jurisdictional claims in published maps and institutional affiliations. 